\title{
Article \\ Assessment of Visual Representation Methods of Linear Discontinuous Deformation Zones in the Right-of-Way
}

\author{
Magdalena Wróblewska * and Marcin Grygierek (D)
}

check for updates

Citation: Wróblewska, M.; Grygierek, M. Assessment of Visual

Representation Methods of Linear Discontinuous Deformation Zones in the Right-of-Way. Appl. Sci. 2022, 12, 2538. https://doi.org/10.3390/ app12052538

Academic Editor: Atsushi Mase

Received: 13 January 2022

Accepted: 24 February 2022

Published: 28 February 2022

Publisher's Note: MDPI stays neutral with regard to jurisdictional claims in published maps and institutional affiliations.

Copyright: (C) 2022 by the authors. Licensee MDPI, Basel, Switzerland. This article is an open access article distributed under the terms and conditions of the Creative Commons Attribution (CC BY) license (https:// creativecommons.org/licenses/by/ $4.0 /)$.

\author{
Department of Geotechnics and Roads, Faculty of Civil Engineering, Silesian University of Technology, \\ 44-100 Gliwice, Poland; marcin.grygierek@polsl.pl \\ * Correspondence: magdalena.wroblewska@polsl.pl
}

\begin{abstract}
Mining impacts on the ground surface may manifest themselves, inter alia, in the form of continuous and discontinuous deformations. Discontinuous deformations significantly deteriorate the condition of the road surface, posing a threat to the safety of use. Therefore, in mining areas, it is necessary to carry out an ongoing inspection of the condition of objects and thus determine the need and scope of their repair. The key method of assessing the scope of the surface repair needed is to observe the road surface. This article presents the results of selected measurement methods carried out near discontinuous deformation zones in the right-of-way. The use of measurements with the use of a laser profilograph allowed determining the evenness of the tested pavement. Additionally, geodetic methods were used: leveling and GPS satellite positioning, to determine the displacement of points forming the observation lines along the right-of-way. In order to identify, in detail, linear discontinuous deformations, non-ceiling photogrammetry was used with the use of an unmanned aerial vehicle. The comparison of selected methods and their advantages and disadvantages allowed for the assessment of their usefulness in visual representation zones of linear discontinuous deformations. The results of this research show the usefulness of laser profilographs, while the greatest detail of the measurement was obtained by low-ceiling photogrammetry with the use of an unmanned aerial vehicle.
\end{abstract}

Keywords: mining influences on the road surface; measurement methods; unmanned aerial vehicles

\section{Introduction}

\subsection{Characteristics of the Influence of Mining Deformations on the Road Surface}

Communication routes, such as roads and rail roads, are of key importance for the functioning of society and the economy of each country. Therefore, this type of linear object is classified as so-called critical infrastructure [1,2]. A special case of the operation of this type of facility is areas of mining activity. Unfortunately, the functioning of roads in mining areas is associated with the occurrence of additional threats resulting from the inevitable deformation of the subsoil. Mining impacts on the ground surface can manifest themselves in the form of continuous and discontinuous deformations, among others. A consequence of mining impacts on building structures, including roads, is additional impacts in the form of displacements and deformations, leading to deterioration of functional features, or even damage to the objects [3-7]. Due to the deterioration or even damage to them, the key issue is the possibility of monitoring the impact of mining operations on their technical condition, as well as obtaining data enabling forecasting of the scope of the technical condition change, in terms of predicting the consequences of the planned mining operation in the line of the linear object.

The two mentioned types of mining deformations, i.e., continuous and discontinuous deformations, understood as breaking the continuity of the rock mass, are considered particularly destructive [3]. Therefore, the deformations observed on the surface may appear in the form of linear deformations: fissures, cracks, faults, while the more dangerous 
cases of discontinuous deformations include so-called surface deformations, which include, for example, sinkholes.

Currently, on the road network in Poland, in the areas of mining exploitation, if there are discontinuous deformations, they are of the linear type. These deformations occur only under certain geological and mining conditions. Their forecasting mainly consists in analyzing the characteristics of the rock mass and mining exploitation conducive to their formation [4]. The main factor in the formation of discontinuous deformations is exploitation at shallow depths, as described by Strzałkowski [8]. The currently conducted deep mining exploitation, i.e., at depths of $300 \div 1000 \mathrm{~m}$ and even deeper, also favors the formation of discontinuous deformations in the case of overlapping of the edges of mining plots [9-11] and/or in the case of a fault in the geological structure of the rock mass over the exploited deposit deck.

Discontinuities in road structures are a serious problem because they deteriorate the condition of the road surface and pose a threat to users' safety (change in pavement evenness) [12]. The results of measuring the pavement deflection with an FWD (falling weight deflectometer) apparatus indicate that when the subsoil and pavement layers loosen, a reduction in the stiffness of the subsoil and pavement layers is observed. Discontinuous deformations appearing on the road surface require repair works at least restoring the evenness of the surface and the required load-bearing capacity [13].

\subsection{Measurement Methods Used to Assess Mining Influences}

The necessity to maintain the road network at a sufficiently high level requires periodic assessment of its technical condition [14]. The basic measurements used in road construction, sensitive to the effects of mining exploitation, include: measurement of longitudinal evenness, measurement of transverse evenness and measurement of pavement deflection, the results of which are used to estimate the fatigue life of the pavement.

In the case of mining areas, research is still necessary to observe changes in the shape of the road lane, including the road. For this purpose, geodetic methods are used. The correctness of the selection of the appropriate method will depend, inter alia, on the expected accuracy, availability of hardware, software and time, availability of measuring points and vision. Among the methods, one can distinguish both classical measurements consisting in the direct measurement of distances, angles and elevations between points, and more modern ones with the use of satellite techniques, photogrammetry and laser scanning [15]. Along with the development of technology, there has also been an automation of geodetic measurements, an example of which is a laser sensor of vibrations, deflections and deformations [16]. Integrated monitoring with the use of automated measuring devices is successfully used in larger facilities, such as bridges and water dams [17].

In order to observe changes in the slope of the road surface, measurements of the observation network are performed (measurement lines with scattered points), e.g., using leveling techniques. Direct field measurement with the use of total station or GPS techniques also enable observations of the arising horizontal displacements [18,19]. Obtaining data for larger areas requires the use of the photogrammetric method (by developing aerial or satellite images), airborne laser scanning (LIDAR) or the method of radar interferometry-InSAR [20-22].

Recently, the use of low-ceiling photogrammetry with the use of unmanned aerial vehicles has become popular [23].

In addition to the control of depressions and changes in the grade line gradient, the parameters of the pavement surface sensitive to subsoil deformations should also be assessed. The most important parameter is the longitudinal evenness of the pavement, which is assessed using the IRI (International Roughness Index). Determining the IRI enables measurement with a laser profilograph. This index was developed by the World Bank in the 1980s [24] and should be equated to the description of the change in the shape of the pavement surface. It is defined as "the accumulated suspension vertical motion divided by the distance traveled as obtained from a mathematical model of a 
simulated quarter-car traversing a measured profile at $80 \mathrm{~km} / \mathrm{h}^{\prime \prime}$ [25]. This index is the basic tool for assessing the quality of the pavement after construction, during use and after modernization [26-30]. The guidelines for calculating the IRI are described in the documents [31,32]. The characteristics between the IRI and driving comfort were presented by Sayers [33] (Figure 1) and Bridgelall et al. [34] (Table 1).

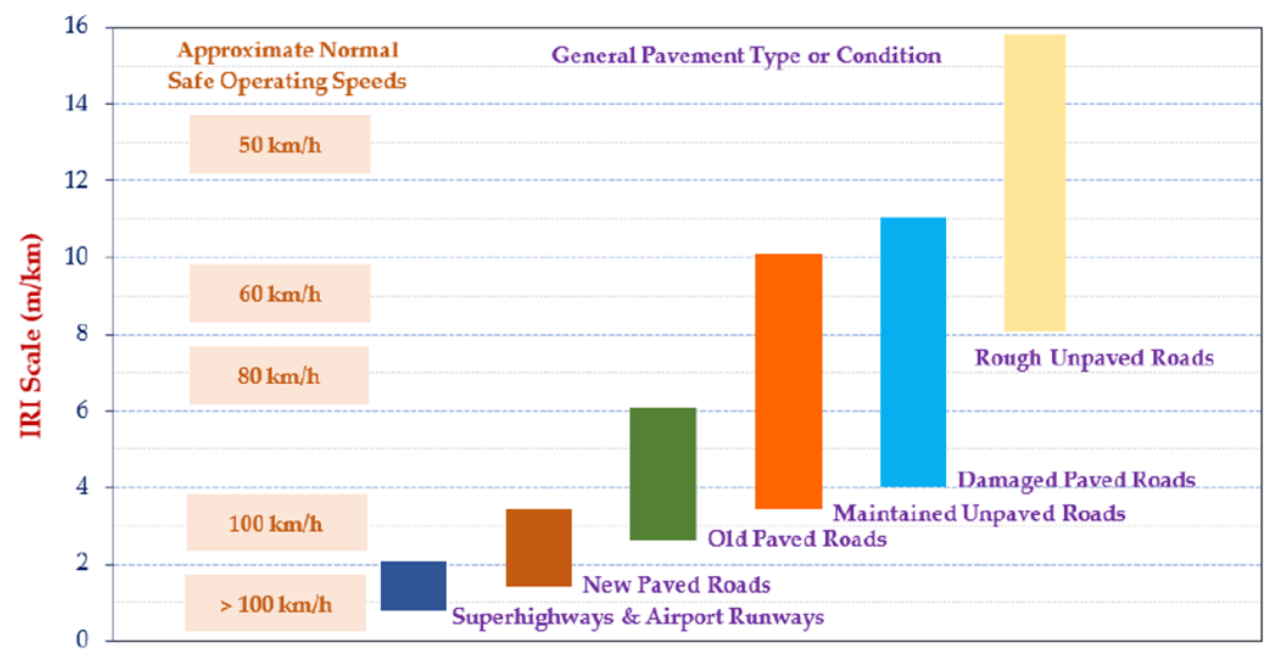

Figure 1. Illustration of the IRI scale for different pavements [33].

Table 1. The relationship of the IRI with the feelings of drivers at different vehicle speeds [34].

\begin{tabular}{ccccccc}
\hline \multirow{2}{*}{$\begin{array}{c}\text { Ride Quality } \\
\text { Level }\end{array}$} & $\mathbf{6}$ IRI Thresholds at Different Speeds $\mathbf{( m / \mathbf { k m } )}$ \\
\cline { 2 - 7 } & $\mathbf{2 0}$ & $\mathbf{4 0}$ & $\mathbf{6 0}$ & $\mathbf{8 0}$ & $\mathbf{1 0 0}$ & $\mathbf{1 2 0}$ \\
\hline Very Good & $<5.72$ & $<2.86$ & $<1.90$ & $<1.43$ & $<1.14$ & $<0.95$ \\
\hline Good & $5.72-8.99$ & $2.86-4.49$ & $1.90-2.99$ & $1.43-2.24$ & $1.14-1.79$ & $0.95-1.49$ \\
\hline Fair & $9.00-11.39$ & $4.50-5.69$ & $3.00-3.79$ & $2.25-2.84$ & $1.80-2.27$ & $1.50-1.89$ \\
\hline Mediocre & $11.40-16.16$ & $5.70-8.08$ & $3.80-5.40$ & $2.85-4.05$ & $2.28-3.24$ & $1.90-2.70$ \\
\hline Poor & $>16.16$ & $>8.08$ & $>5.40$ & $>4.05$ & $>3.24$ & $>2.70$ \\
\hline
\end{tabular}

Due to the widespread use of the IRI, it is also used to develop a correlation with other indicators describing the condition of the pavement, but not relating to the shape of the pavement surface. An example is the PCI (Pavement Condition Index), which uses the assessment of only surface damage, such as: potholes, fatigue cracking, rutting, block cracking, edge cracking, longitudinal and transverse cracking, patching, shoving, bleeding, polished aggregates and raveling [30,35].

\subsection{Research Methodology}

This article presents the results of selected measurement methods carried out in the zone of discontinuous deformations occurring in the right-of-way. The basic research to assess the evenness of the pavement was the measurement with a laser profilograph. This measurement makes it possible to determine the IRI describing the longitudinal evenness of the pavement. The IRI is considered to be one of the basic parameters used to describe the degradation of the technical condition of the pavement $[14,36]$. The IRI is expressed as the value of the longitudinal evenness of the pavement for a $50 \mathrm{~m}$-long section, characterized by linear discontinuous deformations of the pavement, often appearing as a single phenomenon over a $50 \mathrm{~m}$ section; of course, sometimes they are phenomena occurring in a group of several successive ones.

Therefore, the research and analysis were directed to answer the following questions:

- Can the measurement with a laser profilograph and the IRI determined on its basis identify a single inequality in the field? 
- Do other methods currently used in surveying enable precise localization of linear discontinuous surface deformations?

The research used commonly used geodetic measurements: technical leveling and GPS satellite positioning, in order to determine the displacements of points forming the observation lines along the right-of-way. For the detailed identification of linear discontinuous deformations, low-ceiling photogrammetry was used with the use of an unmanned aerial vehicle. The graph of the measurement methods used in this research is shown in Figure 2.

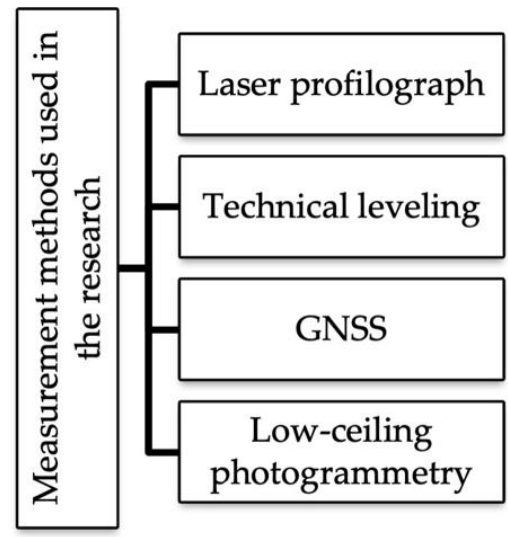

Figure 2. Graph of the measurement methods used in this research.

The comparison of the selected methods and their advantages and disadvantages allowed for the assessment of their usefulness in visual representation zones of linear discontinuous deformations.

\section{Characteristics of the Research Area}

\subsection{Road Characteristics}

The research area is located in the southern part of Silesia Province. The subject of the observation is a road of regional importance (Figure 3). This section is under the influence of deep mining exploitation, conducted for many years, and the road was built and commissioned in 2017. The road has a cross-section with one road and two traffic rights-of-way. The right-of-way width is $3.50 \mathrm{~m}$, and the shoulder is $2.50 \mathrm{~m}$. The road has KR6 [37] traffic, which corresponds to the penultimate highest traffic load category. The road has a flexible pavement, with a thickness of $32 \mathrm{~cm}$ and mineral-asphalt layers and layers of an unbound mixture on the lower ground. In addition, a $60 \mathrm{~cm}$-thick geomaterial is used in the layer system, which should, to a large extent, reduce deformations on the road surface.

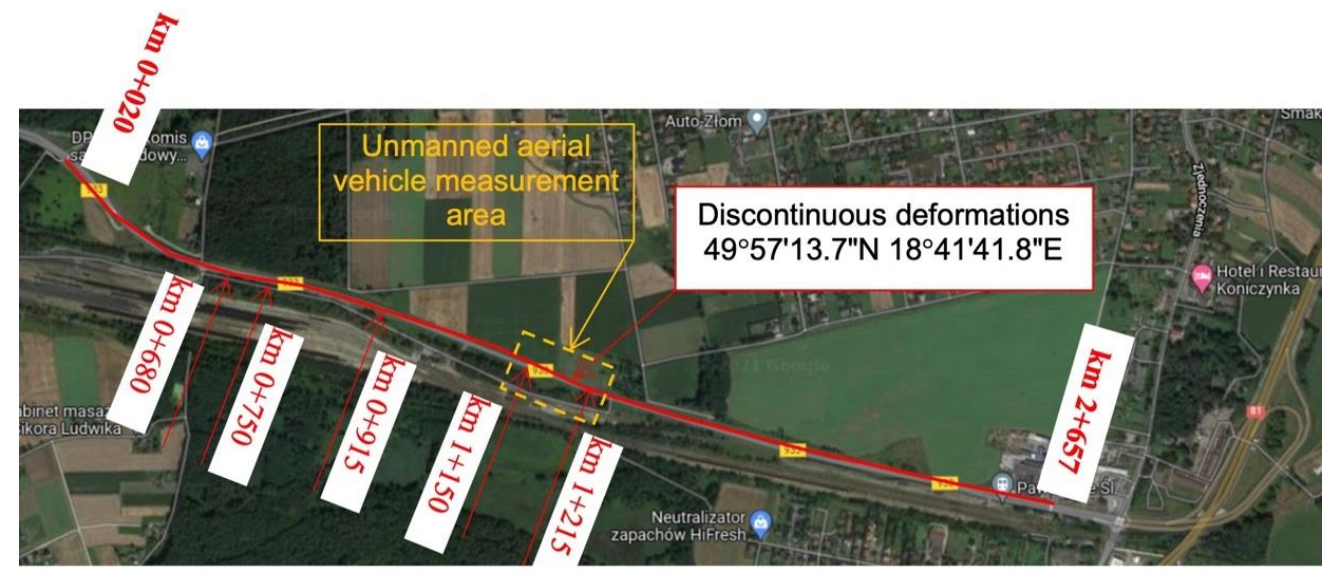

Figure 3. Location of the tested road section. 
The conducted underground mining exploitation caused damage to the road surface. There are two areas of damage, namely, area 1: from $\mathrm{km} 0+680$ to $\mathrm{km} 0+915$, and area 2: from $\mathrm{km} 1+150$ to $\mathrm{km} 1+215$. The damage in area 1 (Figure 4) occurred before 2021; this area was not the main subject of the observation. Damage in area 2 (Figures 5 and 6) occurred in March 2021 as a consequence of underground mining operations conducted there. There are two basic types of damage, i.e., pavement unevenness and transverse cracks of considerable width, and mutual displacement of the pavement edges in the vertical plane (Figure 7).

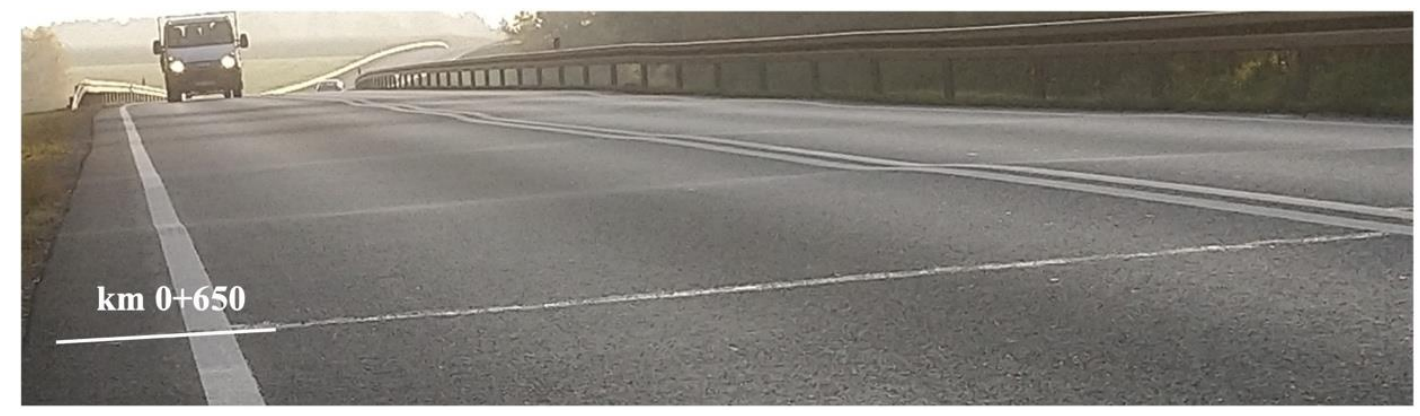

Figure 4. Example of a continuous deformation of the road surface on the section from $\mathrm{km} 0+680$ to km $0+750$.

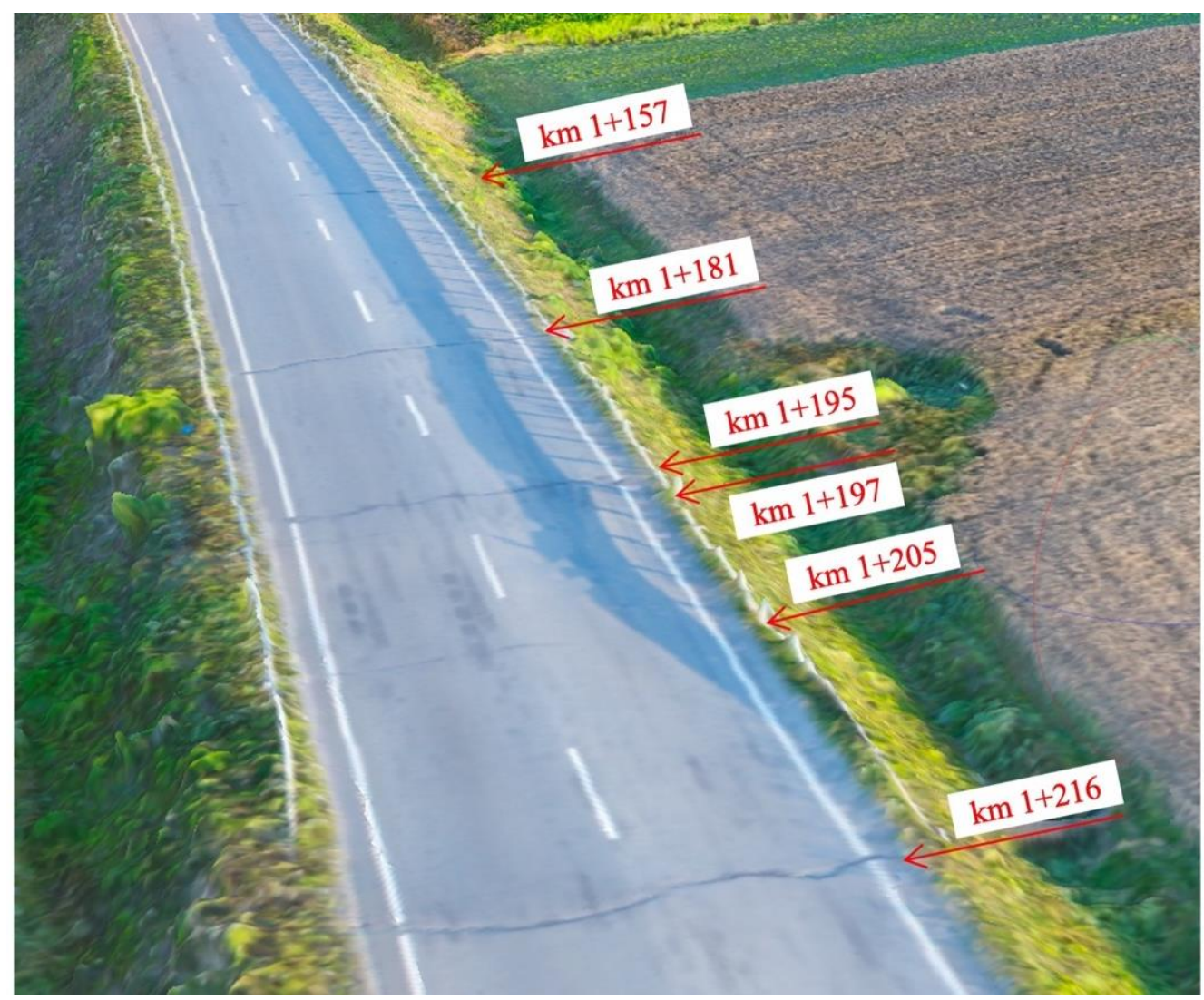

Figure 5. Location of pavement damage in the zone of linear discontinuous deformations occurring in 2021. 


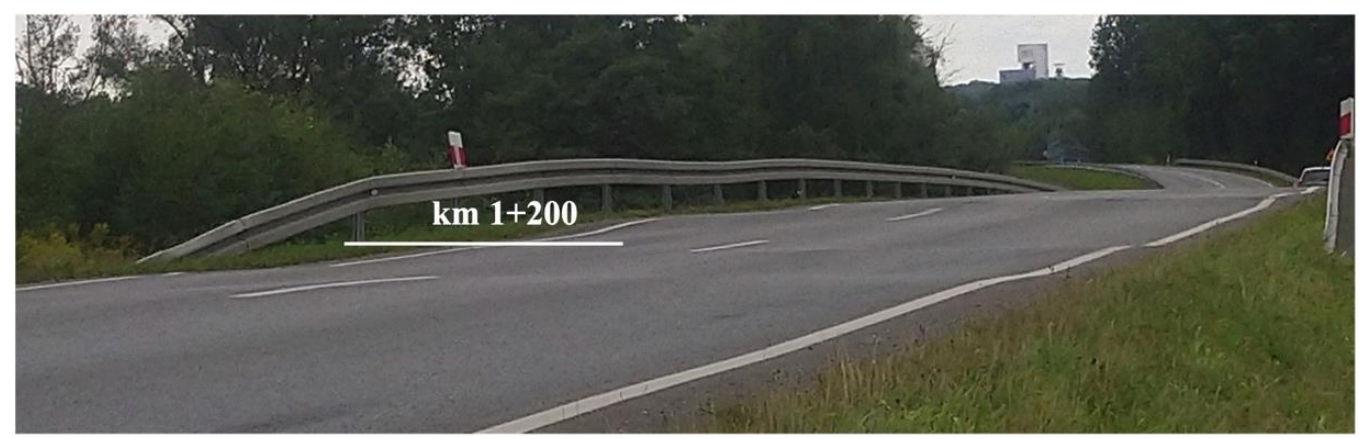

Figure 6. Example of a continuous deformation of the road surface on the section of about $\mathrm{km} 1+200$.
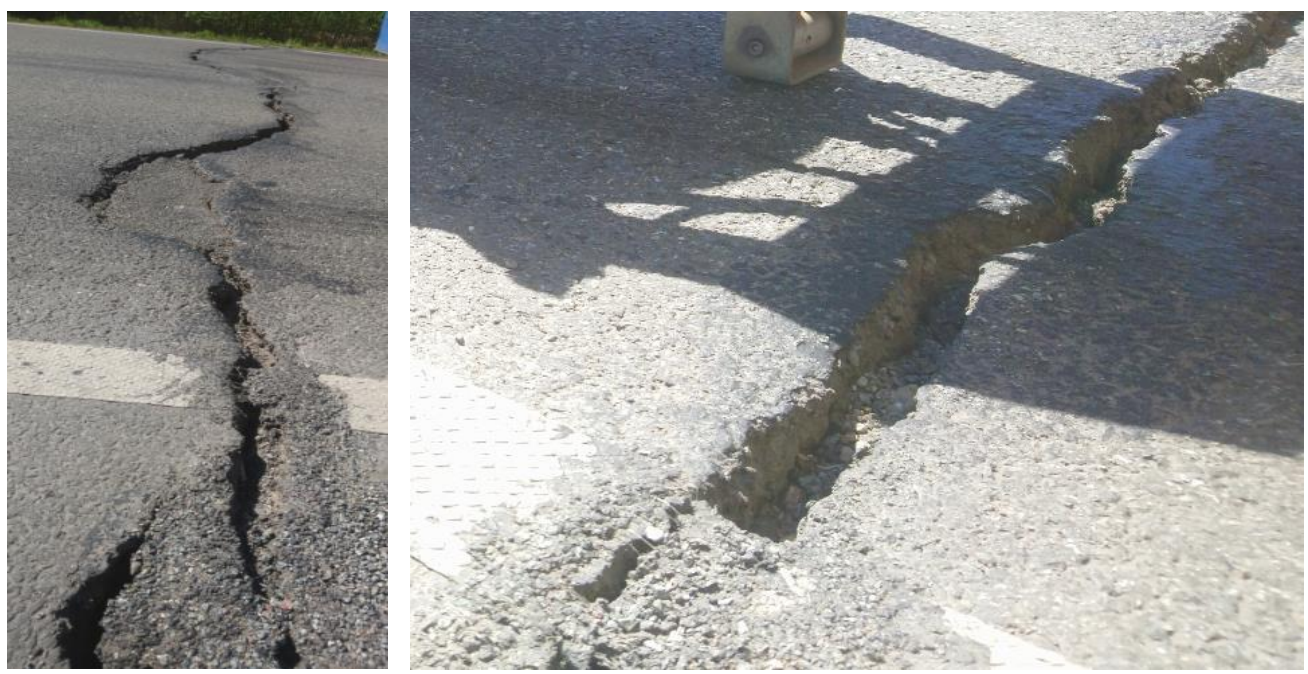

Figure 7. Examples of pavement damage caused by mining at $\mathrm{km} 1+216$.

\subsection{The Mining and Geological Situation}

The area constituting the research area is intensively influenced by the underground mining operation carried out from 1974 at a depth of up to $1000 \mathrm{~m}$. The location of the edges of the mining longwalls in the background of the research area is shown in Figure 8. In the area of the observed measurement line, the exploitation causes mining influences on the surface corresponding to the IV category of the mining area.

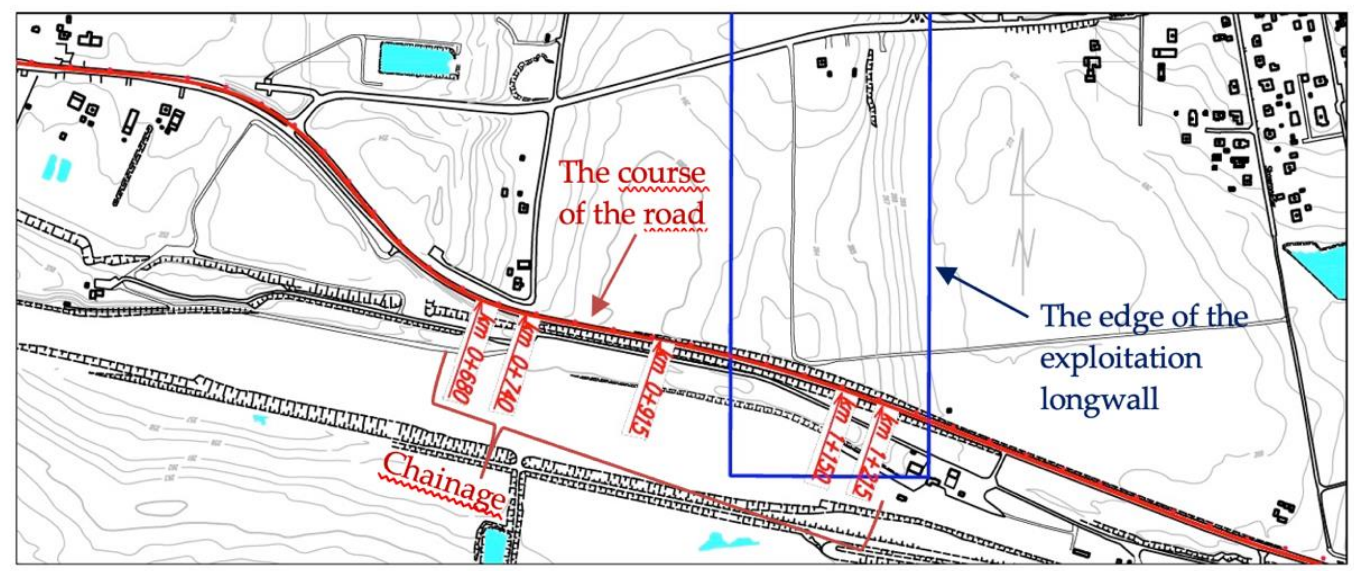

Figure 8. Location of a longwall exploited in 2021 under a right-of-way.

The Carboniferous formations with deposits of hard coal are involved in the geological structure of the area. Directly on the Carboniferous formations, there are Tertiary forma- 
tions, represented mainly by loams, and Quaternary formations, represented by dusty clay with an admixture of dusty sand.

\section{Research in Right-of-Way}

\subsection{Longitudinal Evenness of the Road Surface}

The longitudinal evenness of the pavement was measured on the analyzed road section using a mobile laser profilograph. The measurement allowed determining the IRI $(\mathrm{mm} / \mathrm{m})$ in accordance with [36,37]. A Polish-made laser profilograph, HSP9011, was used for the research (Figure 9). The measurement accuracy of the device complies with the requirements of Polish regulations on the systemic assessment of the pavement condition [14] (Table 2). The measurement was conducted in the longitudinal profile in the left right-of-way.

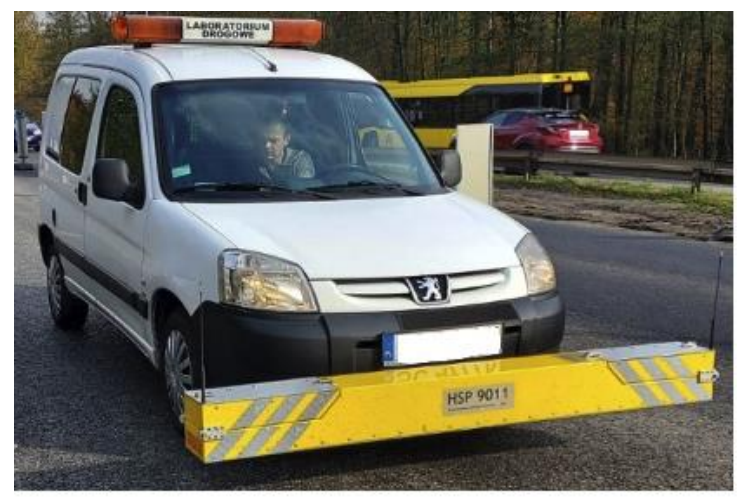

Figure 9. Laser profilograph used to measure the longitudinal evenness of the tested road section.

Table 2. Parameters for a laser profilograph to measure longitudinal evenness.

\begin{tabular}{cccc}
\hline Parameter Name & Unit & $\begin{array}{c}\text { Required Scope and Class of the } \\
\text { Profilograph }\end{array}$ \\
\hline $\begin{array}{c}\text { Vertical resolution } \\
\text { of the laser sensor }\end{array}$ & {$[\mathrm{mm}]$} & $\leq 0.2$ & Class 1 \\
\hline $\begin{array}{c}\text { Longitudinal signal } \\
\text { sampling interval }\end{array}$ & {$[\mathrm{mm}]$} & $\leq 50$ & Class 1 \\
\hline $\begin{array}{c}\text { Interval of recording } \\
\text { profile ordinates in the } \\
\text { measurement file }\end{array}$ & {$[\mathrm{mm}]$} & $\leq 100$ & Class 1 \\
\hline Long-wave filter $(-3 \mathrm{~dB})$ & {$[\mathrm{m}]$} & $\geq 100$ & Class 1 \\
\hline
\end{tabular}

The calculated IRI (Figure 10) represents the equality of the $50 \mathrm{~m}$-long measurement section [14]. The detailed methodology of calculating the IRI is described in $[14,31,32,38]$. The binding regulations require that, for this class, none of the IRI values should be higher than $3.4 \mathrm{~mm} / \mathrm{m}$ [39].

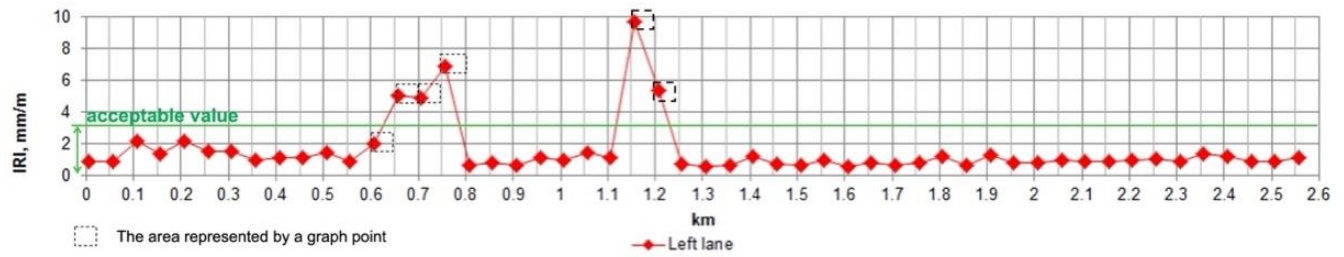

Figure 10. The longitudinal evenness graph of the tested road section obtained with a laser profilograph. 
The distribution of the calculated values of the IRI shows that the permissible inequalities have been exceeded on the section from $\mathrm{km} 0+600$ to $\mathrm{km} 0+800$ and on the section from $\mathrm{km} 1+100$ to $\mathrm{km} 1+250$. The indicated sections of roughness correspond to the location of sections with visible deformations: area 1 (Figure 3), from $\mathrm{km} 0+680$ to $\mathrm{km} 0+750$ (effects of mining operations before 2021), and area 2 (Figures 3 and 5-7), from $\mathrm{km} 1+150$ to $\mathrm{km} 1+245$.

\subsection{Situational and Height Measurements}

As part of the research program, the situational and height measurement of the measurement points was performed. Field measurements refer to the observation line consisting of 37 stabilized points along the right-of-way (Figures 11 and 12). The distance between the points was $50 \mathrm{~m}$.

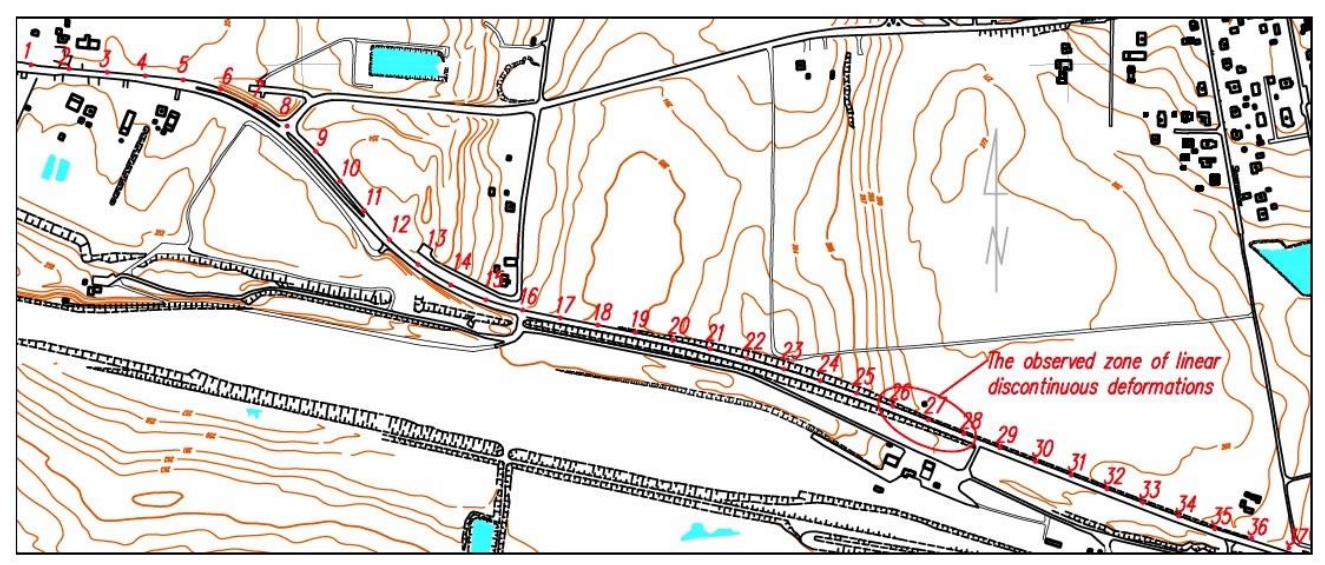

Figure 11. Location of the measurement line with the marked area revealing linear discontinuous deformations.

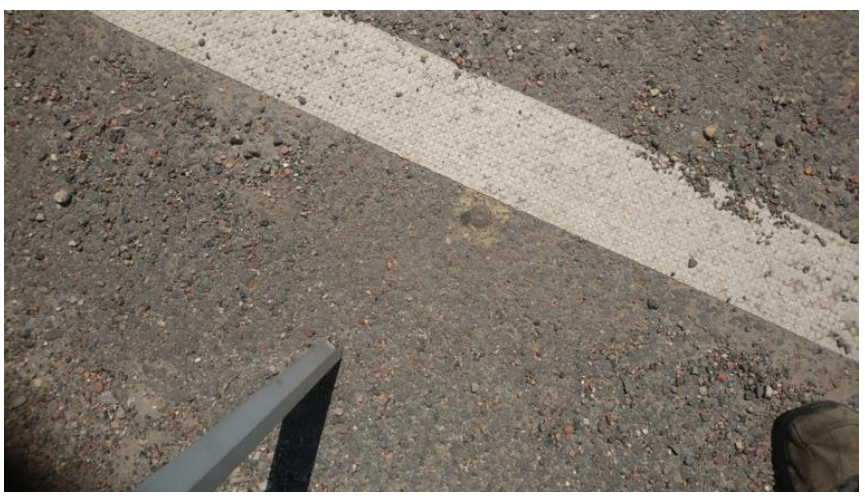

Figure 12. Stabilization of points along the right-of-way.

Classic geometric leveling was performed with the use of an optical leveler with an accuracy of $+/-1-2 \mathrm{~mm}$. At the same time, a measurement was performed with the use of the GNSS (global navigation satellite system) technique with the use of the RTK (real-time kinematic) method. The real state of the road surface was recreated using low-ceiling photogrammetry with the use of an unmanned aerial vehicle (drone). Detailed data of the raid are presented in the next chapter of this article.

The results of the obtained ordinates of the observation line measurement points with the division into the measurement methods performed are shown below (Figure 13). 


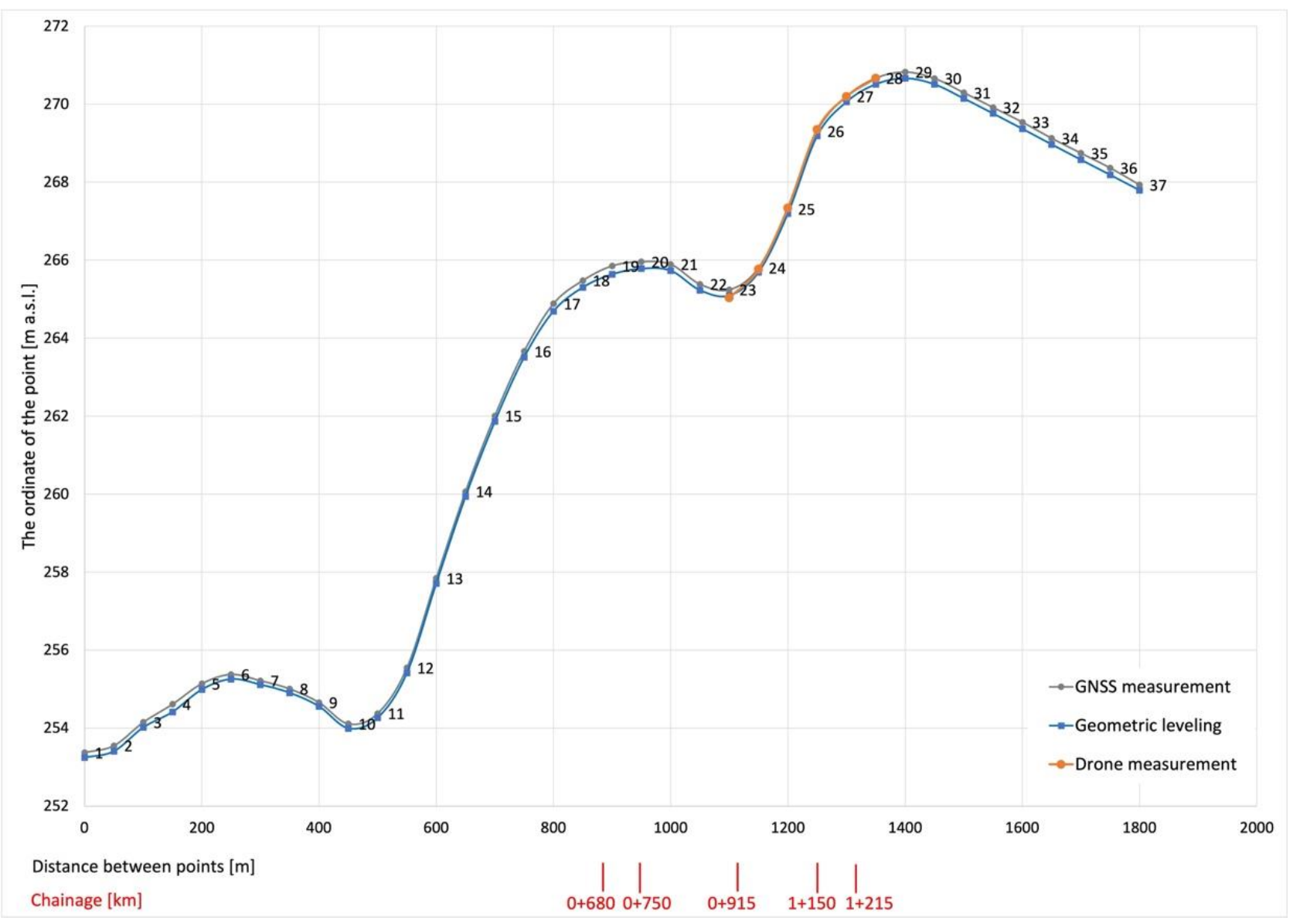

Figure 13. Graph of point ordinates for the observed measurement line with the division into the measurement methods used.

As can be seen from the graph above, a good agreement of the measurements performed with the use of three different measurement methods was obtained. Due to the length of the measurement section and the distribution of measurement points every $50 \mathrm{~m}$, using the classic methods, the revealed deformations of the pavement were not sufficiently captured. Hence, in the further part of the analysis, the possibilities of using data from low-ceiling photogrammetry for detailed identification of the resulting zones of linear deformation were examined.

\subsection{Measurement with an Unmanned Aerial Vehicle}

Photogrammetric measurement with the use of an unmanned aerial vehicle consisted in taking a series of photos, which were then processed using a specialized program. A point cloud was generated, where each tracked point in the field received $x, y$ and $\mathrm{z}$ coordinates.

The raid was carried out using a quadcopter weighing over $1.3 \mathrm{~kg}$. The equipment had a camera with a 1-inch $20 \mathrm{MP}$ sensor. A mission with the following flight settings was planned over the area of revealed discontinuous deformations:

- Flight trajectory (double grid) usually dedicated to 3D models;

- $\quad$ Flight altitude of $60 \mathrm{~m}$, which translates into a $1.5 \mathrm{~cm}$ field pixel;

- $\quad$ Speed of $4 \mathrm{~m} / \mathrm{s}$;

- Camera angle of 80 degrees;

- Lateral and longitudinal coverage of photos of $80 \%$. 
The mission lasted about 18 min, during which 233 photos were taken.

The photogrammetric processing began with the alignment of the photos and the identification of ground control points (previously measured with a GNSS). This stage allowed for the generation of a dense point cloud. Due to the limitations of the processing equipment, the process was performed at medium precision settings.

The obtained 3D model of the zone of linear discontinuous deformations on the tested road surface is shown in Figure 14.

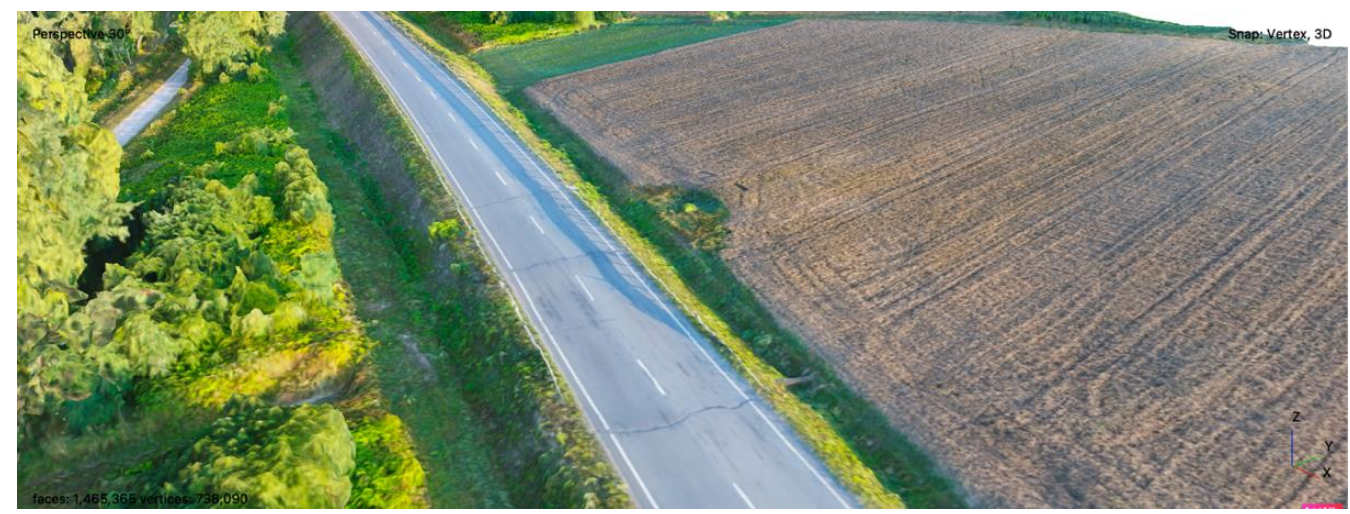

Figure 14. Three-dimensional visualization obtained as a result of the UAV flight over the zone of linear discontinuous deformations on the road surface.

At the post-processing stage, a hypsometric map was also created (Figure 15) using the following color scale-from dark green (representing the lowest area) to orange (for the highest area). Following the location of the observation line, the course of the longitudinal profile was determined, starting from $1.1 \mathrm{~km}$ at point 23 to $1.35 \mathrm{~km}$, represented by point 28 . The elevation of the terrain with the marked area of deformation is shown in Figure 16.

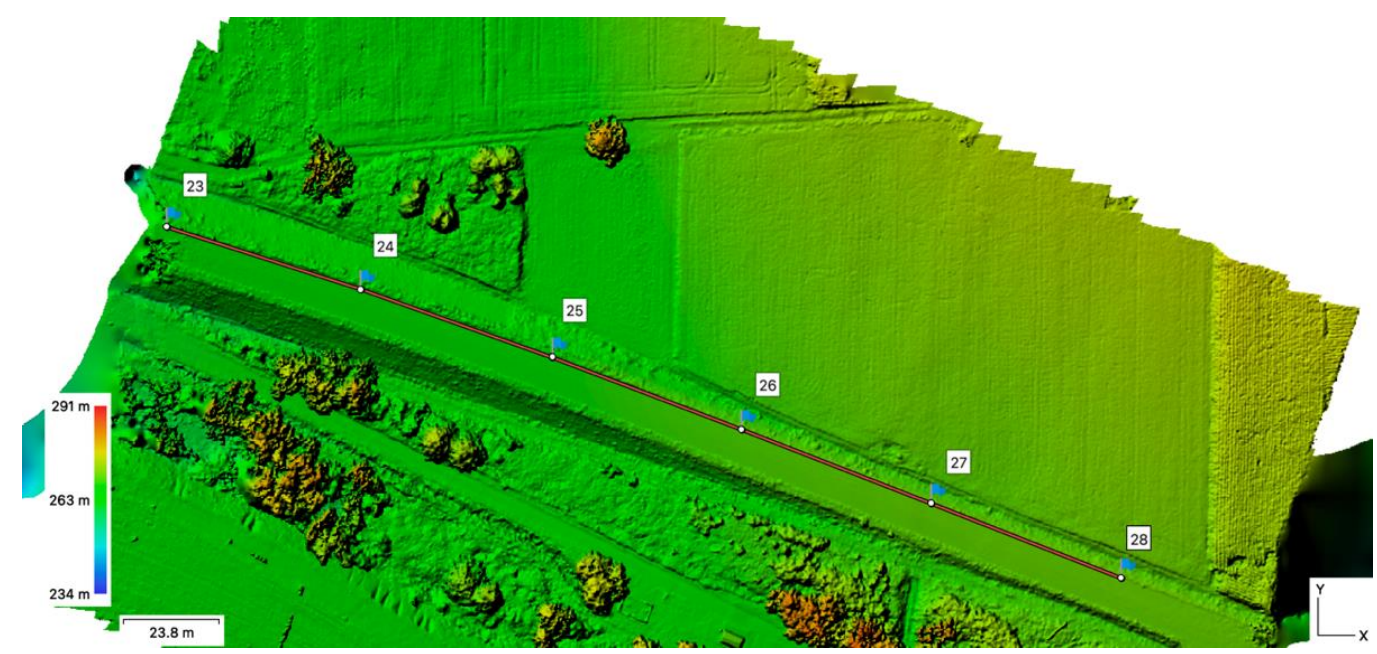

Figure 15. DEM model with a defined course of the longitudinal profile. 


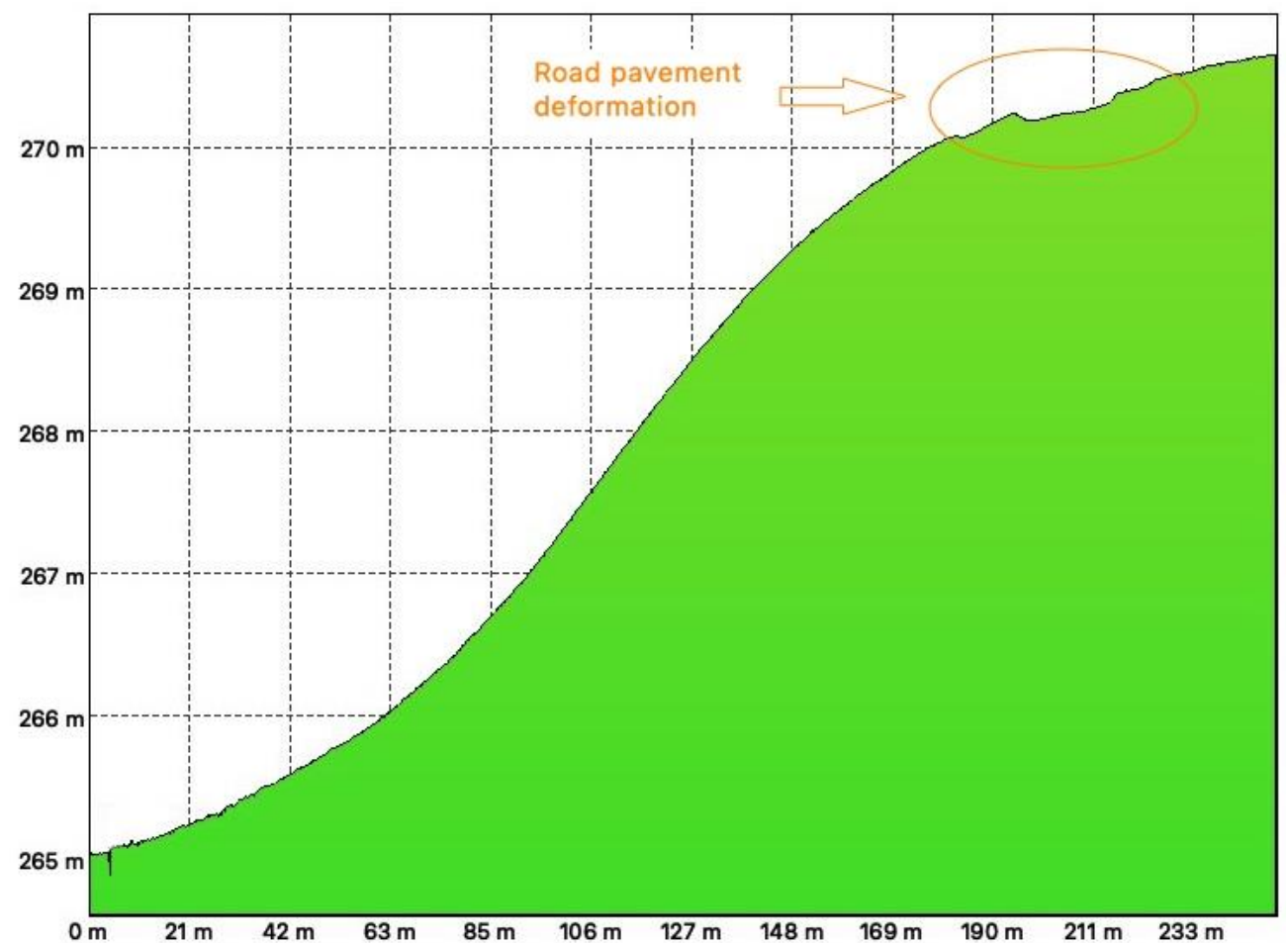

Figure 16. Longitudinal profile of the section shown in Figure 15 together with the marked section of the deformed road surface.

\section{Analysis of the Grade Line in the Identification of Discontinuities-The Use of Data from the UAV Raid}

The analysis of the identification of discontinuous deformations was started with the compaction of the measurement points, for which the location was obtained as a result of processing data from the UAV (unmanned aerial vehicle) flight. In the first stage, it was necessary to determine the optimal distance between the measurement points. As the stabilized field points were located at a distance of $50 \mathrm{~m}$, it was decided to compact the measurement points starting from a distance of $20 \mathrm{~m}$ (point group " $\mathrm{a}$ ") and then stepwise reduce the distance between the points-15 m (point group " $\mathrm{b}$ "), $10 \mathrm{~m}$ (point group " $\mathrm{c}$ ") and $5 \mathrm{~m}$ (point group " $\mathrm{d}$ "). For each group of generated measurement points, the pavement surface heights (Figure 17a-d), the slope of the pavement surface (Figure 18a-d) and the curvature of the pavement surface of the measurement sections (Figure 19a-d) were determined. The heights of the pavement surface at individual points (groups from " $a$ " to " $\mathrm{d}$ ") were read from the hypsometric map (Figure 15). The next parameters describing the shape of the pavement surface were calculated on the basis of the read ordinates and the distance between the points, i.e., the slope according to Relation (1), and the curvature according to Relation (2), according to [7].

$$
T=\frac{\Delta w_{A B}}{d_{A B}}
$$

where:

$T$-slope/tilt between two points, $A$ and $B$;

$\Delta w$-difference in subsidence between two points, $A$ and $B$;

$d$-distance between two points, $A$ and $B$;

$A, B, C \ldots-$ consecutive points forming the measurement line.

$$
K=\frac{T_{B C}-T_{A B}}{d_{a v}}
$$

where: 
$K$-curvature between two sides, $A B$ and $B C$;

$T_{B C}-T_{A B}$ - change in the slopes of the adjacent sides $A B$ and $B C$;

$d_{a v}$-average distance between points $A, B$ and $C$;

$A, B, C \ldots-$ consecutive points forming the measurement line.

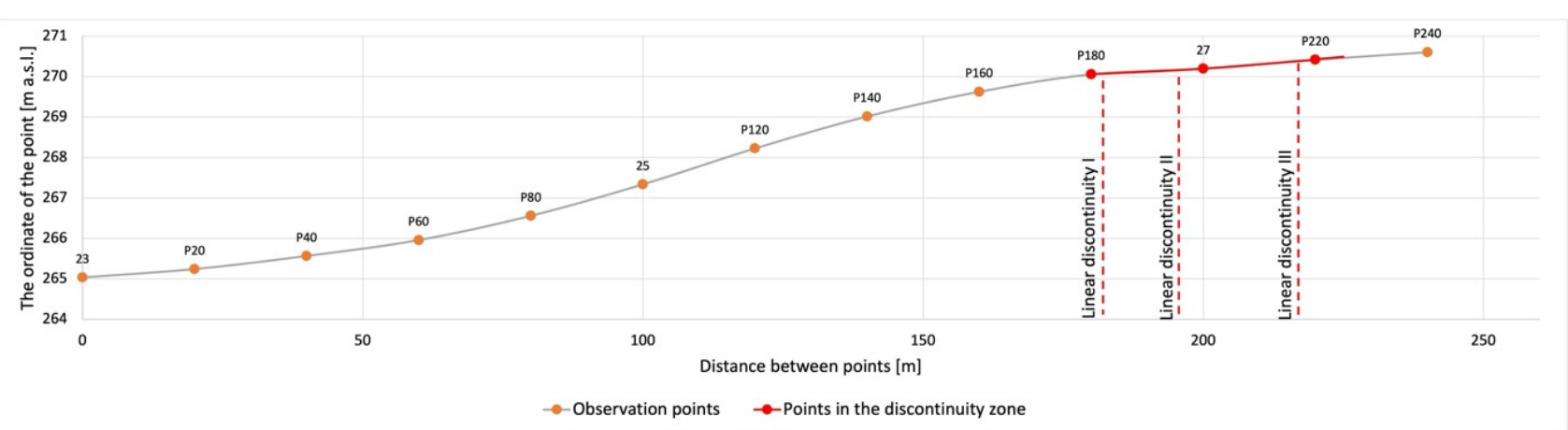

(a)

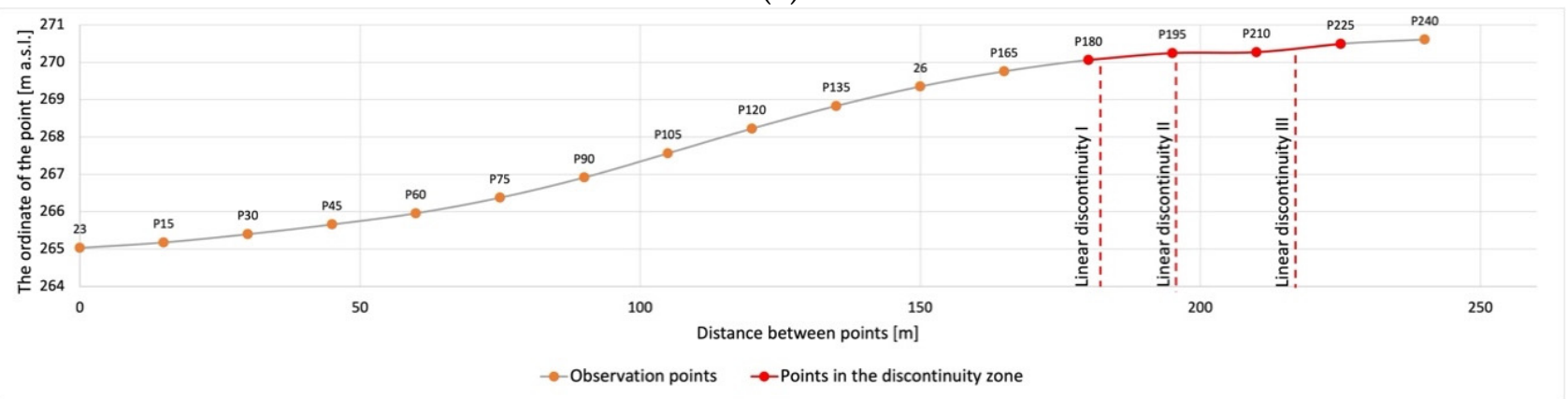

(b)

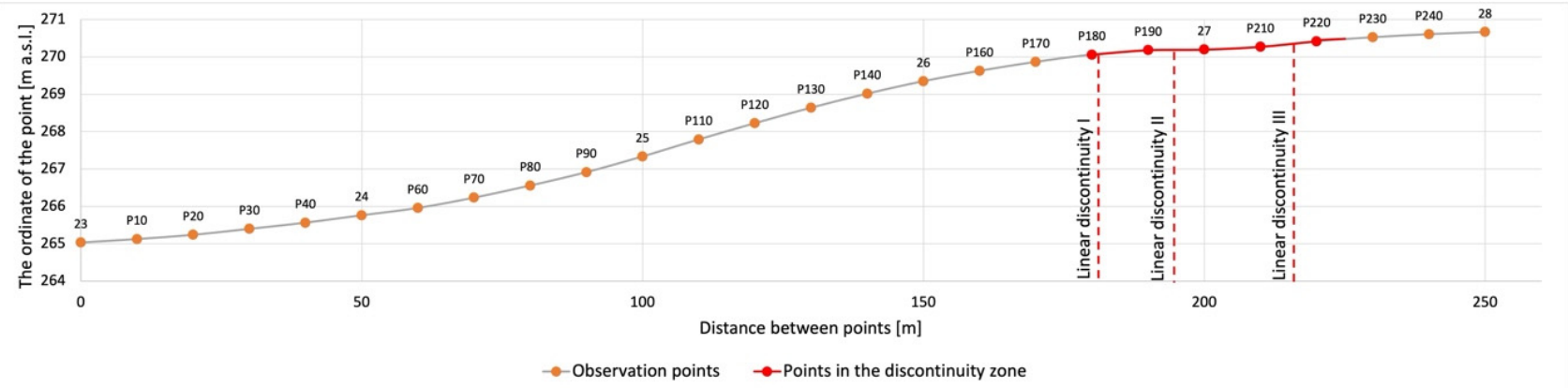

(c)

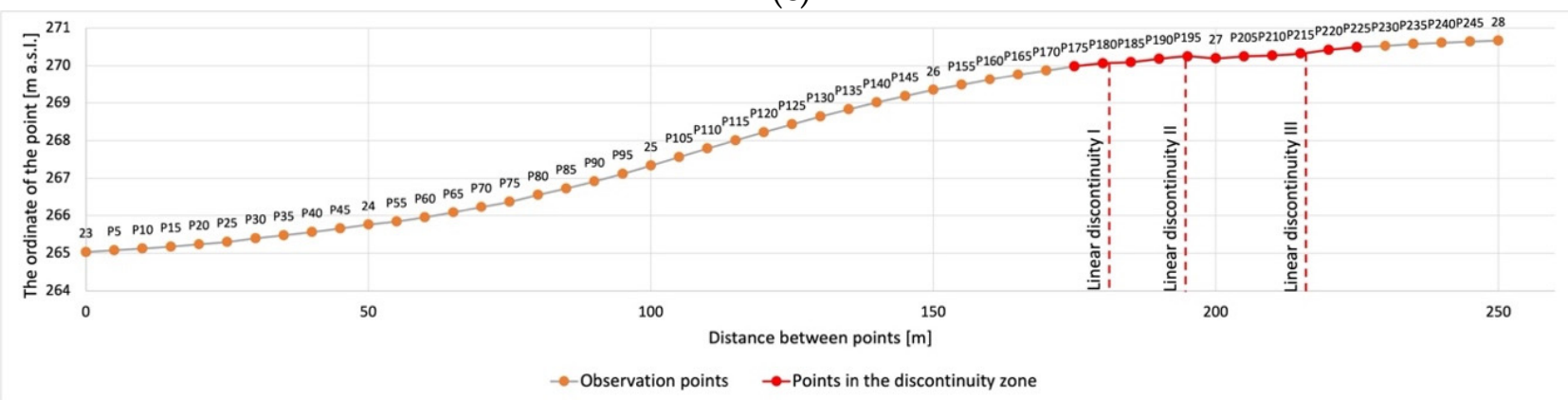

(d)

Figure 17. Graphs of lowering measurement points located at a distance of (a) $20 \mathrm{~m}$, (b) $15 \mathrm{~m}$, (c) $10 \mathrm{~m}$ and (d) $5 \mathrm{~m}$. 


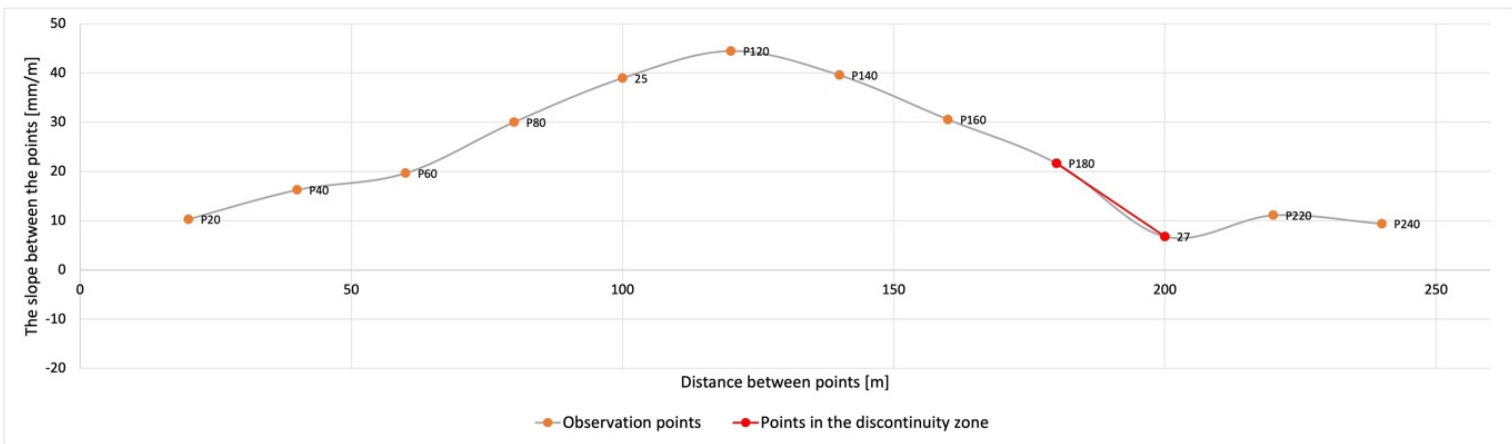

(a)

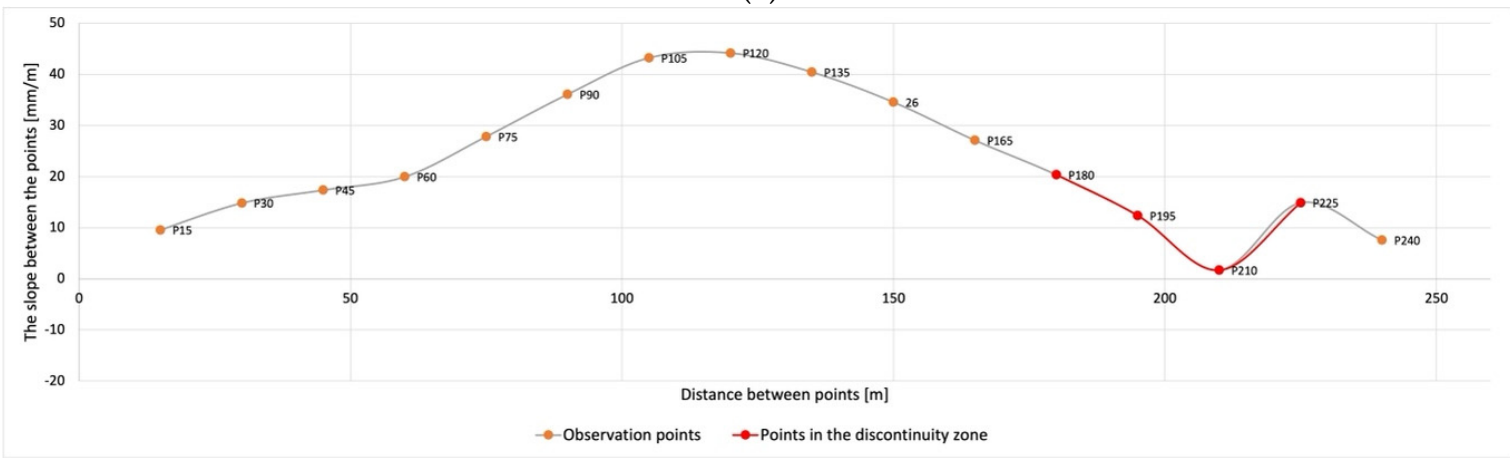

(b)

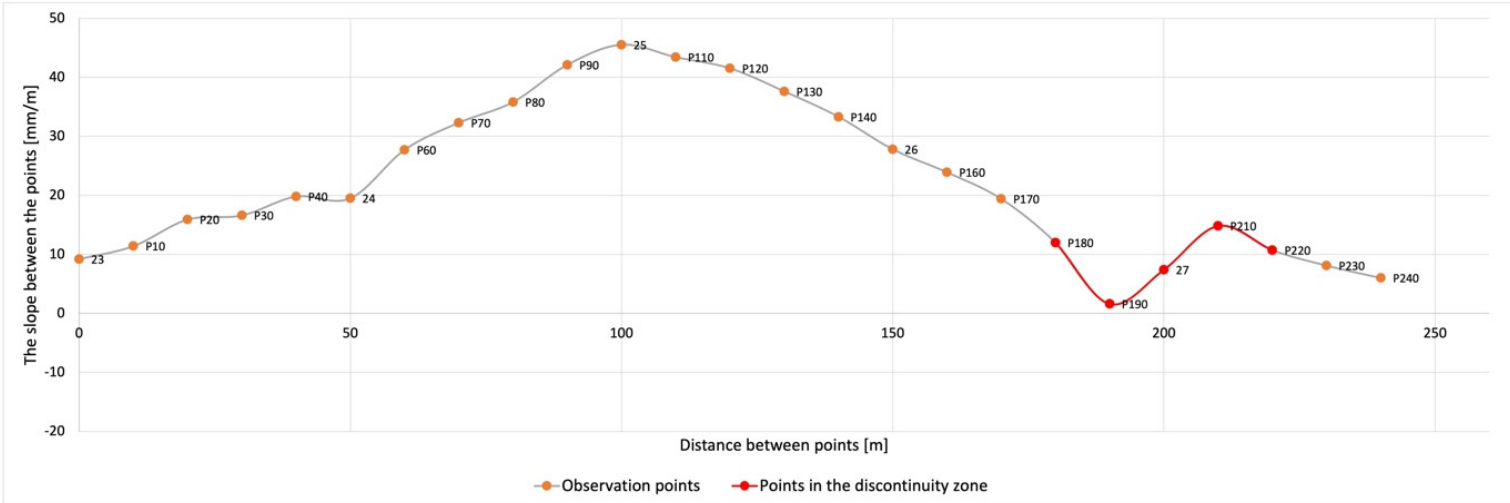

(c)

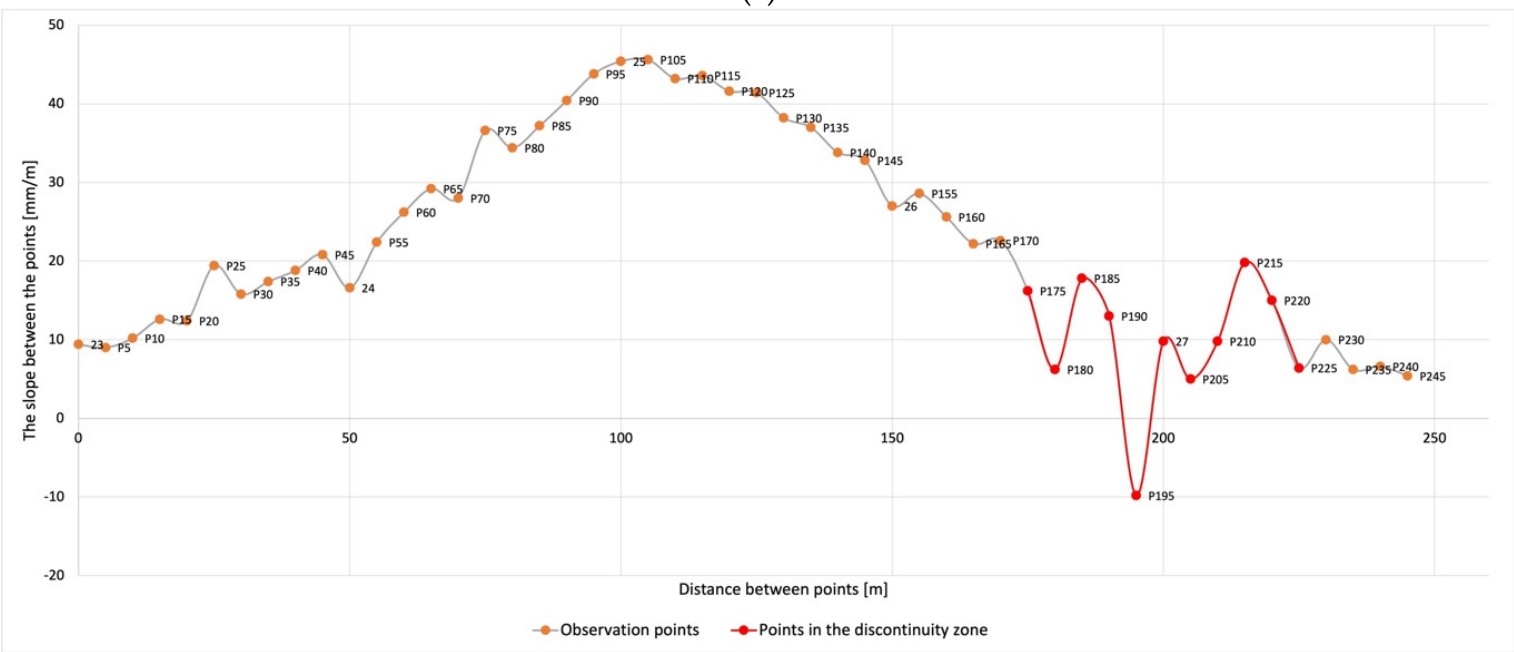

(d)

Figure 18. Slope (T) graphs between measurement points at a distance of (a) $20 \mathrm{~m}$, (b) $15 \mathrm{~m}$, (c) $10 \mathrm{~m}$ and (d) $5 \mathrm{~m}$. 


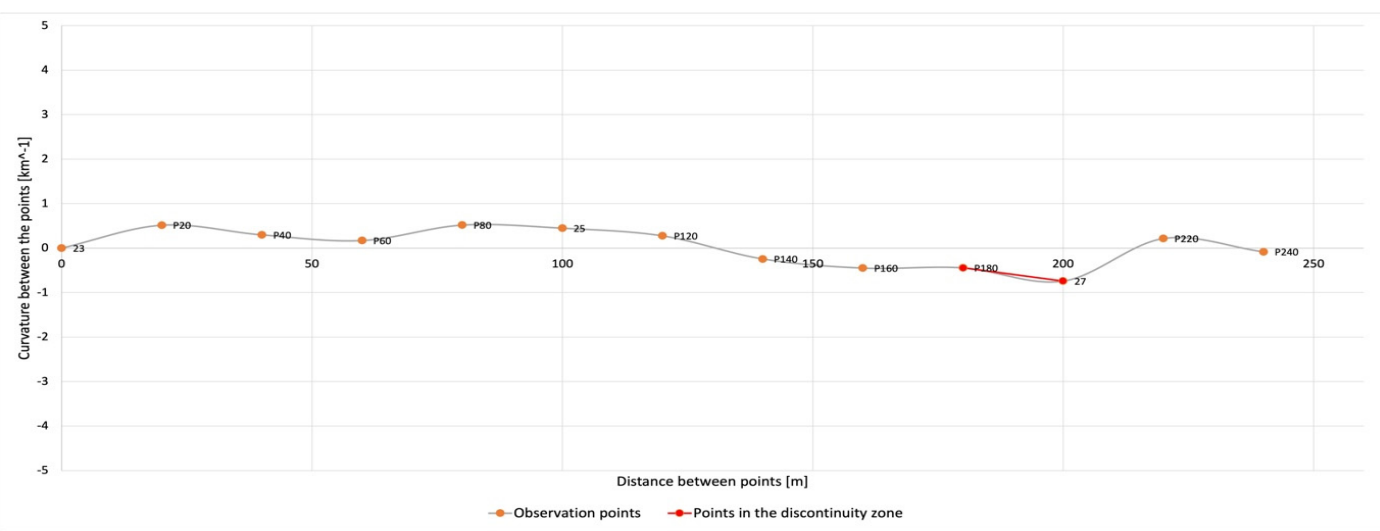

(a)

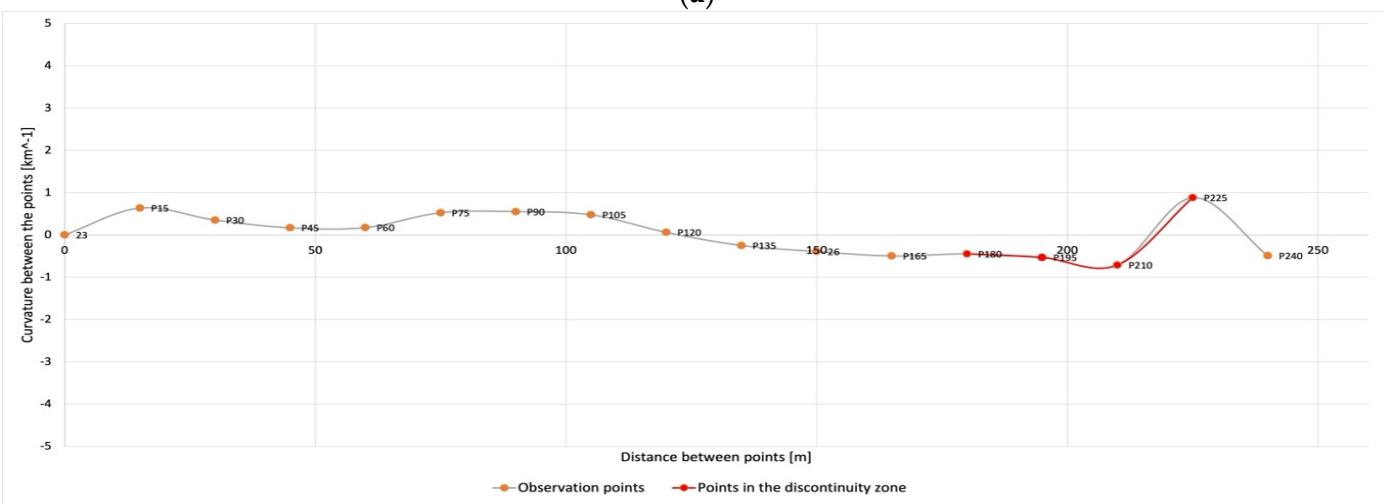

(b)

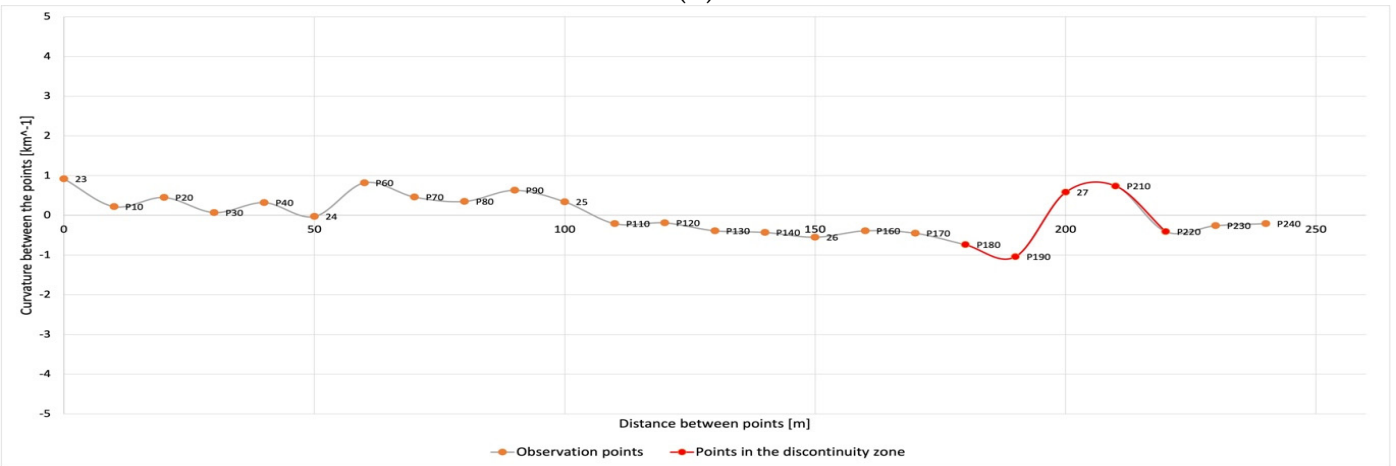

(c)

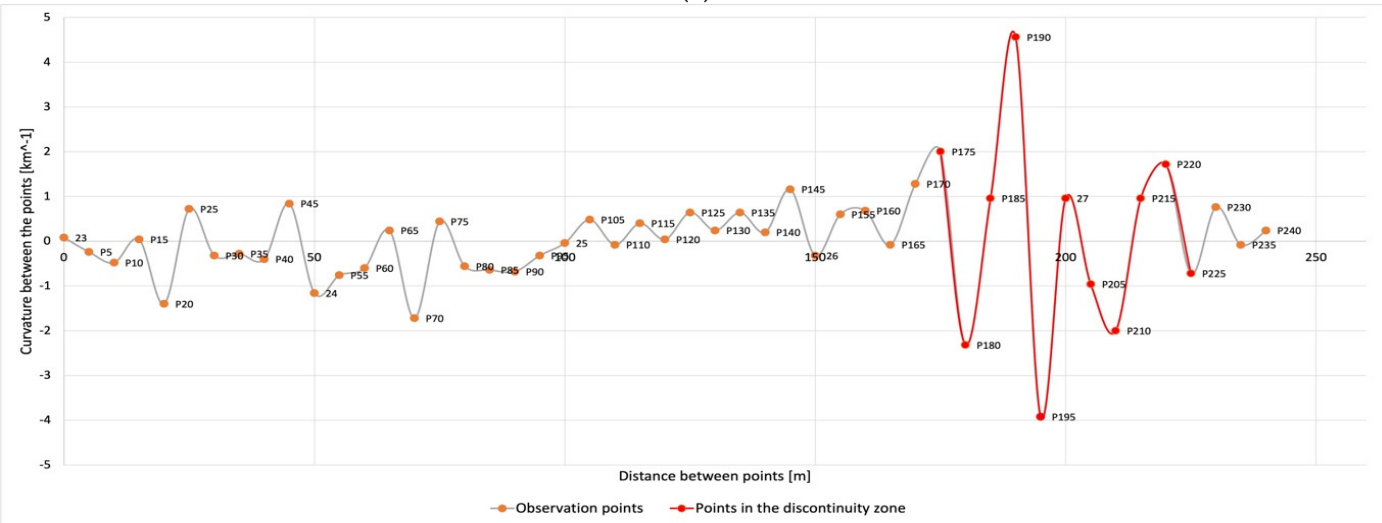

(d)

Figure 19. Curvature (K) graphs between measurement points at a distance of (a) $20 \mathrm{~m}$, (b) $15 \mathrm{~m}$, (c) $10 \mathrm{~m}$ and (d) $5 \mathrm{~m}$. 
The analysis of additional parameters $(\mathrm{T})$ and $(\mathrm{K})$ describing the topography was aimed at searching for the parameter most sensitive to the identification and isolation of the deformed section of the pavement surface.

Both in the case of the slope $(\mathrm{T})$ and curvature $(\mathrm{K})$ of the pavement surface, a gradual identification of the discontinuous deformation zone is noticeable. Along with the densification of the measurement points, greater fluctuations for the discontinuous deformation zone are observed in relation to the other measurement points. The greatest fluctuations in the area of discontinuous deformations in relation to the remaining sections are observed in the case of curvature (K) and point density every $5 \mathrm{~m}$ (point group " $\mathrm{d}$ ") (Figure 19d).

In the next stage of the analysis, it was considered whether it was possible to present the distribution of the curvature of the pavement surface so as to emphasize only the area of discontinuous deformations against the rest of the area whose surface corresponds to the correct shape. The correct shape of the pavement surface was assumed to be the one that does not cause negative feelings for the driver due to the vibration of the vehicle, which, of course, also applies to the IRI (Figure 10). It seems that a satisfactory parameter that can be used as a measure for the fluctuation of the curvature distribution is the standard deviation (3). The standard deviation was always calculated for the set of four consecutive points.

$$
\sigma=\sqrt{\frac{\sum_{i=1}^{n}\left(K_{i}-K_{a v}\right)^{2}}{(n-1)}}
$$

where:

$\sigma$-standard deviation;

$K_{i}$ - consecutive curvature values;

$K_{a v}$-arithmetic average of the curvature values;

$n$-number of points.

The distribution of the standard deviation value is shown in Figure 20 for points at a distance of $20 \mathrm{~m} \mathrm{(a),} 15 \mathrm{~m} \mathrm{(b),} 10 \mathrm{~m} \mathrm{(c)} \mathrm{and} 5 \mathrm{~m} \mathrm{(d)}$.

The assessment of the distribution of standard deviations shows that, along with the densification of the measurement points, a more pronounced increase in the standard deviation in the area of discontinuous deformations is observed. The distribution of values for points spaced every $20 \mathrm{~m}$ does not identify the area of discontinuous deformations at all. The differences between the discontinuous deformation area and the rest of the road area are visible only in the case of the points spaced every $15 \mathrm{~m}$ (Figure 20b). In this case, the standard deviation in the deformation area is, at maximum, $\sigma=1.0 \mathrm{~km}^{(-1)}$, and outside the deformation area, it is less than $\sigma<0.5 \mathrm{~km}^{(-1)}$. There is a $100 \%$ difference in the deviation value here. Unfortunately, the area of deformation in terms of length is not as clearly defined (Figure 20b) as in the case of the points spaced every $10 \mathrm{~m}$ (Figure 20c) or every $5 \mathrm{~m}$ (Figure 20d). The most precise area of discontinuous deformations is identified for points spaced every $5 \mathrm{~m}$ (Figure 20d). In this case, the standard deviation outside the deformation area is $\sigma<1.0 \mathrm{~km}^{(-1)}$, and in the area of inequality, it is $\sigma=3.4 \mathrm{~km}^{(-1)}$ at maximum, and thus there is a difference of more than $300 \%$. 


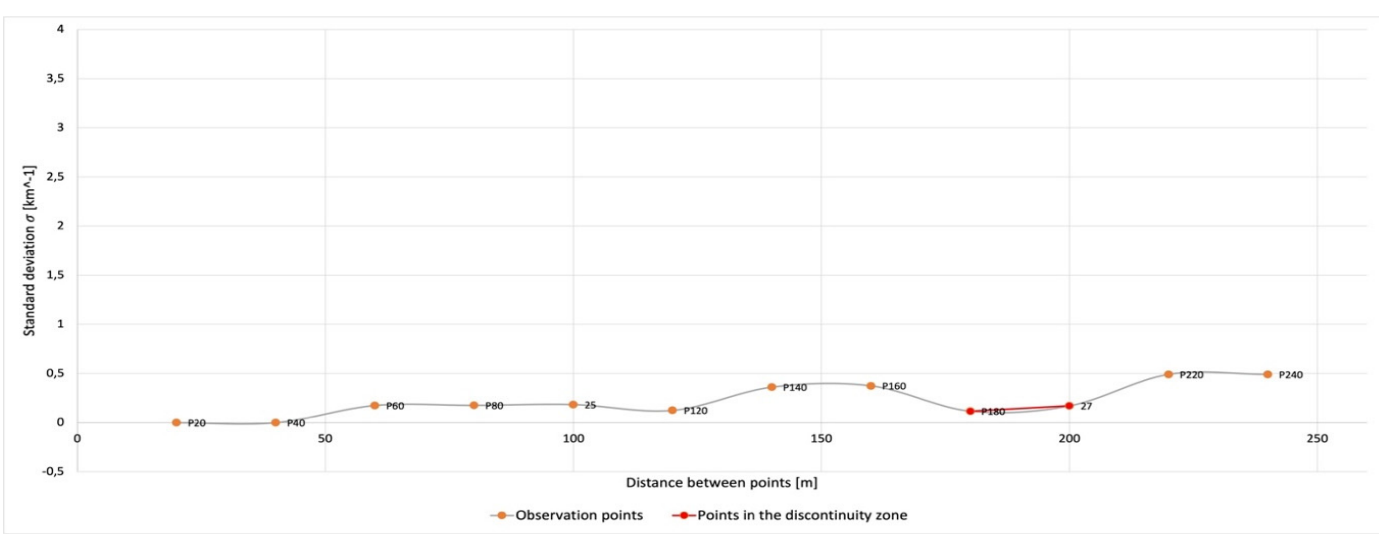

(a)

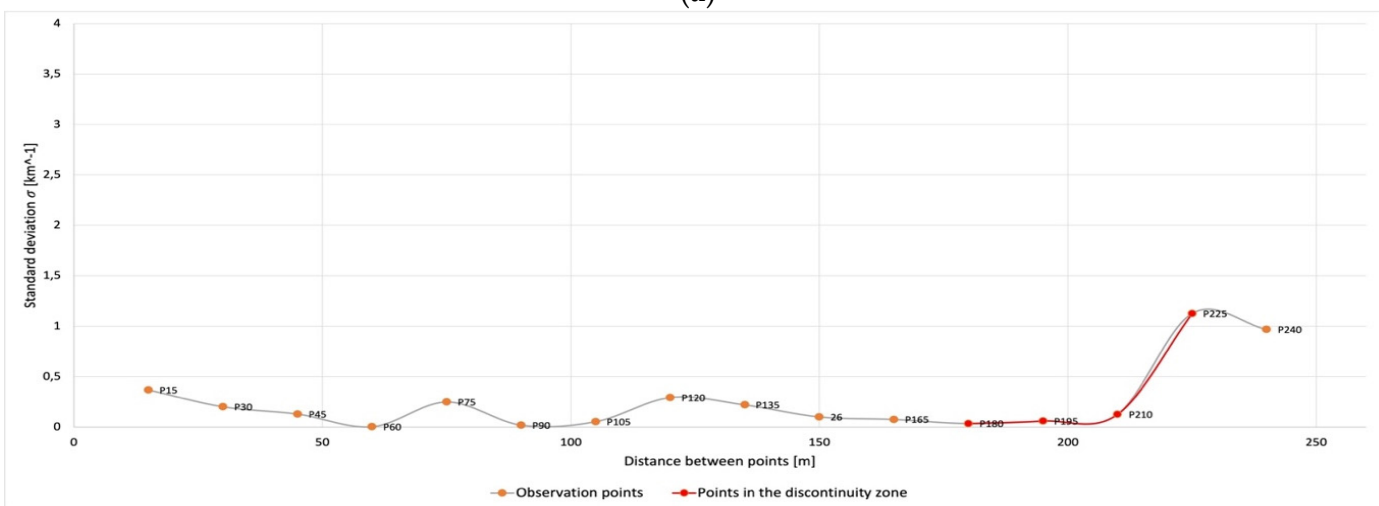

(b)

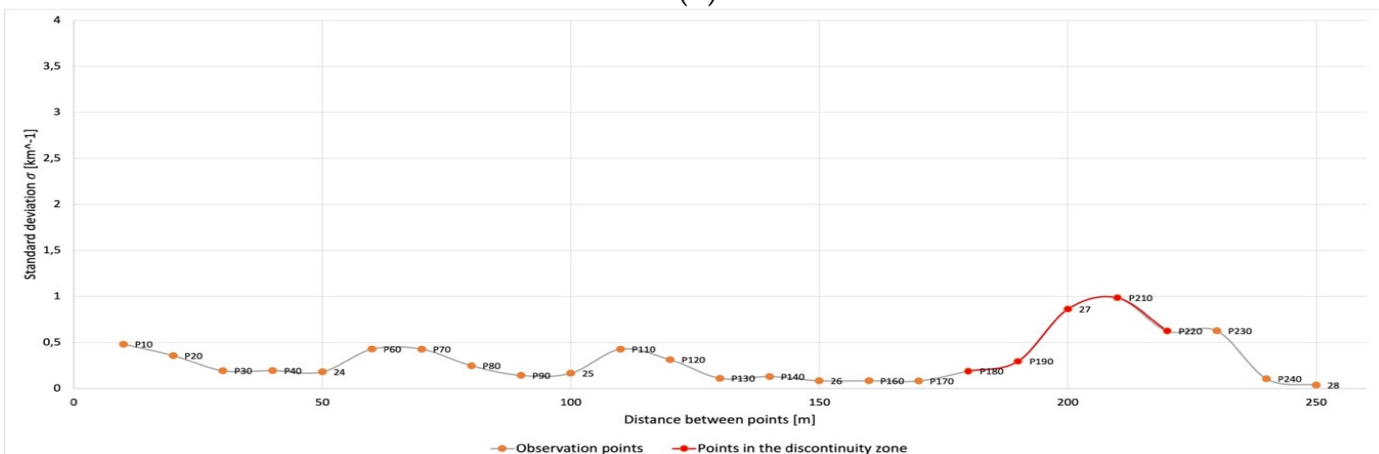

(c)

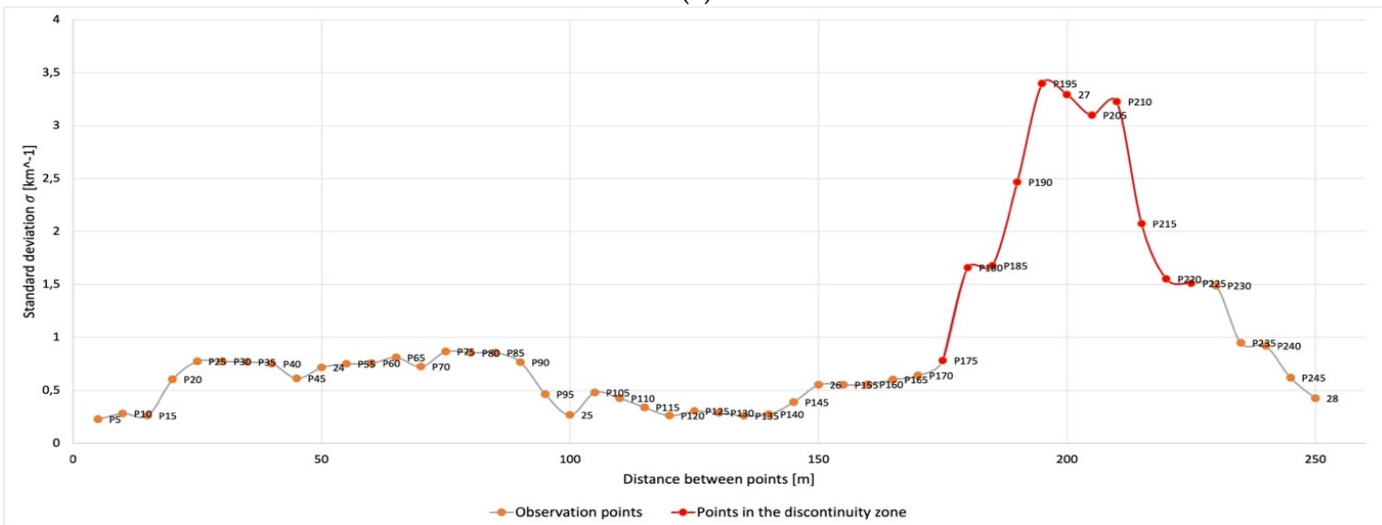

(d)

Figure 20. Standard deviation $(\sigma)$ graphs for measurement points at a distance of (a) $20 \mathrm{~m},(\mathbf{b}) 15 \mathrm{~m}$, (c) $10 \mathrm{~m}$ and (d) $5 \mathrm{~m}$. 


\section{Discussion}

The conducted analysis of data from field research shows that the area of surface unevenness caused by discontinuous deformations can be determined on the basis of measurement with a mobile laser profilograph or on the basis of measurement with an unmanned aerial vehicle. Both measurement methods enable a large number of signal sampling points (profilograph measurement-Table 1) or a high density of measurement points $\left(285\right.$ points $\left./ \mathrm{m}^{2}\right)$. Limiting the analysis to only the common area tested by both methods, i.e., with an unmanned aerial vehicle and a mobile profilograph-the section from $\mathrm{km} 1+000$ to $\mathrm{km} 1+250$-it should be noted that:

- The distribution of the IRI determines the range of pavement surface unevenness from $\mathrm{km} 1+150$ to $\mathrm{km} 1+250$ (Figure 10). The range is determined by the multiplicity of the measurement section length $(50 \mathrm{~m})$. The available data made it possible to analyze only measurement sections with a length of $50 \mathrm{~m}$.

- The distribution of the standard deviation from the next four values for the curvature of the pavement surface sets the range from P180 $(\mathrm{km} 1+181-3 \times 50 \mathrm{~m})$ to P230 ( $\mathrm{km} 1+231)$. In this section, the standard deviation of the surface curvature increases by up to $300 \%$ in relation to the adjacent sections.

The section of the pavement determined on the basis of the distribution of the IRI is longer than the section determined on the basis of the analysis of data from the UAV measurement (Figure 21). Taking the sections shorter than $50 \mathrm{~m}$ into the calculation of the IRI, it will be possible to narrow the range of pavement unevenness.

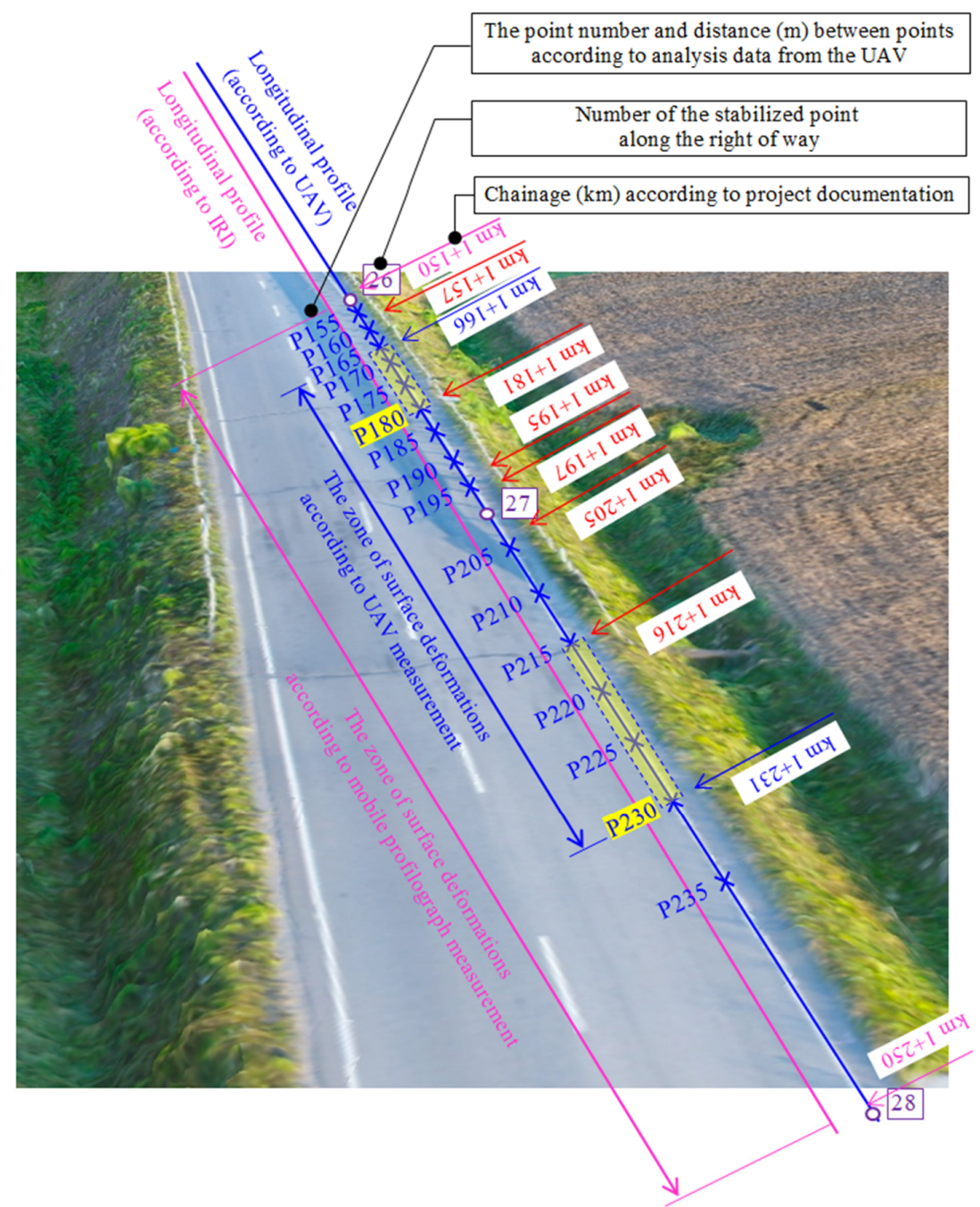

Figure 21. Summary of data analysis results from measurements: UAV and mobile profilograph. 
The analysis of the obtained test results also comes down to the evaluation of the applied measurement methods. For this purpose, the evaluation criteria were selected with the division presented in (1) in Table 3. The evaluation of the measurement methods applied concerns a fragment of the test site from $\mathrm{km} 1+180$ to $\mathrm{km} 1+226$ in the analyzed mining area.

Table 3. List of selected properties of the measurement methods used.

\begin{tabular}{|c|c|c|c|c|}
\hline \multirow{2}{*}{$\begin{array}{l}\text { Criteria for the } \\
\text { Evaluation of the } \\
\text { Measurement } \\
\text { Method }\end{array}$} & \multicolumn{2}{|c|}{$\begin{array}{c}\text { Methods Used } \\
\text { in Engineering Practice }\end{array}$} & \multicolumn{2}{|c|}{$\begin{array}{l}\text { Methods Used } \\
\text { in Own Research }\end{array}$} \\
\hline & $\begin{array}{l}\text { Technical } \\
\text { Leveling }\end{array}$ & GNSS & $\begin{array}{c}\text { Laser } \\
\text { Profilograph }\end{array}$ & $\begin{array}{l}\text { Low-Ceiling } \\
\text { Photogrammetry }\end{array}$ \\
\hline (1) & (2) & (3) & (4) & (5) \\
\hline $\begin{array}{l}\text { Measurement type } \\
\text { (measured } \\
\text { quantity) }\end{array}$ & $\begin{array}{c}\text { Altitude } \\
\text { measurement } \\
(Z)^{*}\end{array}$ & $\begin{array}{l}\text { Situational and } \\
\text { altitude } \\
\text { measurement } \\
(X Y Z)\end{array}$ & $\begin{array}{l}\text { Measurement of } \\
\text { height differences } \\
(\Delta Z)\end{array}$ & $\begin{array}{l}\text { Situational and } \\
\text { altitude } \\
\text { measurement } \\
(X Y Z)\end{array}$ \\
\hline $\begin{array}{l}\text { Accuracy of } \\
\text { measurement }\end{array}$ & $+/-1 \mathrm{~cm}-2 \mathrm{~cm}(\mathrm{Z})$ & $\begin{array}{l}+/-3 \mathrm{~cm}(\mathrm{XY}) \\
+/-5 \mathrm{~cm}(\mathrm{Z})\end{array}$ & $+/-0.5 \mathrm{~mm} / \mathrm{m}$ & $\begin{array}{l}+/-4 \mathrm{~cm}(X Y) \\
+/-5 \mathrm{~cm}(Z)\end{array}$ \\
\hline $\begin{array}{l}\text { The detail of the } \\
\text { measurement }\end{array}$ & $50 \mathrm{~m}$ & $50 \mathrm{~m}$ & $50 \mathrm{~m}$ & $\begin{array}{c}\text { Any } \\
\text { (unlimited) }\end{array}$ \\
\hline $\begin{array}{c}\text { Time of } \\
\text { measurement }\end{array}$ & Long & Short & Short & Short \\
\hline $\begin{array}{l}\text { Data processing } \\
\text { time }\end{array}$ & Short & Short & Short & Long ** \\
\hline $\begin{array}{l}\text { Phenomena } \\
\text { limiting the } \\
\text { measurement }\end{array}$ & $\begin{array}{c}\text { Single } \\
\text { measurement up } \\
\text { to } 50 \mathrm{~m}\end{array}$ & $\begin{array}{c}\text { Lack of vision, } \\
\text { propagation } \\
\text { disruptions }\end{array}$ & $\begin{array}{l}\text { Surface } \\
\text { humidity }\end{array}$ & $\begin{array}{l}\text { Weather } \\
\text { phenomena: } \\
\text { strong wind, } \\
\text { rainfall }\end{array}$ \\
\hline $\begin{array}{l}\text { Additional } \\
\text { remarks }\end{array}$ & $\begin{array}{l}\text { The need to refer } \\
\text { to the benchmark }\end{array}$ & - & - & $\begin{array}{l}\text { Preparatory } \\
\text { activities } \\
\text { in the field- } \\
\text { establishing } \\
\text { ground control } \\
\text { points (GCPs) }\end{array}$ \\
\hline
\end{tabular}

$\bar{*}$ In the case of the reference to the national benchmark. ${ }^{* *}$ Depends on computer parameters. ${ }^{* * *}$ For better measurement accuracy.

The measurement methods presented in this article have their advantages and disadvantages. Undoubtedly, the advantage of classic methods such as technical leveling is full independence from electronic systems and weather conditions. The accuracy of such measurements will mainly depend on the accuracy of the observer's readings and the accuracy of the equipment. On the other hand, GNSS satellite positioning offers the possibility of obtaining complete data in the form of $\mathrm{x}, \mathrm{y}$ and $\mathrm{z}$ coordinates in real time, which allows for the determination of land depressions and horizontal displacements at the same time. What is important, however, is proper visibility in the field. Both in classical leveling and GNSS positioning, the detail of the obtained results depends on the number of measured points in the field.

In the case of the photogrammetric method, great opportunities were noticed at the stage of data processing. Compared to the previous methods, the measurement time is the shortest. The obtained accuracy depends, among others, on: the accuracy of the equipment, the amount of flight time, the number of GCPs and weather conditions. Despite the many advantages, such as the speed of measurement or the great possibilities at the post-processing stage, UAV measurements performed over road structures also have their disadvantages, such as the presence of continuous vehicle traffic and vegetation, which can distort the image obtained from the raid. 


\section{Conclusions}

Mining exploitation causes damage to the ground surface, affecting the parameters of the road surface. These changes may pose a threat to road users; therefore, there is a need to periodically assess pavement deformation. In the case of identification of the zones of linear discontinuous deformations and assessment of their influence on the pavement evenness, continuous observations are required. For this purpose, both classic (leveling, GNSS, laser profilographs) and modern measurement techniques (UAV) can be used. Among the commonly used measurement methods, the laser profilograph is the most useful. The presented experiments allow demonstrating the location of pavement unevenness in the case of unevenness characterized by a threshold of at least $2-3 \mathrm{~cm}$ high or an IRI $=2-3 \mathrm{~mm} / \mathrm{m}$ at minimum. Additionally, the tested surface is made of SMA (stone mastic asphalt). Very promising results were obtained with the use of low-ceiling photogrammetry with the use of an unmanned aerial vehicle, which made it possible to identify road surface deformations with appropriate detail. Accurate imaging was possible thanks to the high resolution of the camera along with the selected flight parameters (flight altitude of $60 \mathrm{~m}$, coverage of lateral and longitudinal photos of $80 \%$, camera angle of $80^{\circ}$, using a double flight trajectory). Higher accuracy was also achieved thanks to the GCPs.

The search for the optimal length of the measurement sections showed that the points with a spacing of $5 \mathrm{~m}$ to $10 \mathrm{~m}$ allowed visualizing the zone of linear discontinuous deformations. Increasing the distance between points above $10 \mathrm{~m}$ causes excessive averaging of the observed data. Despite the large number of preparatory activities and weather conditions, measurements with the use of unmanned aerial vehicles have a great potential in identifying discontinuous linear deformations of the surface.

Research on the use of modern measurement techniques to identify pavement damage, among other features, should be continued due to the wide range of possibilities, especially at the data processing stage. Future work should, first of all, expand the base of the tested pavement cases with revealed discontinuous deformations with the use of UAVs. An interesting direction of research would be an attempt to correlate the IRI and the longitudinal evenness determined with the help of data from a UAV flight

Author Contributions: Conceptualization, M.W. and M.G.; methodology, M.G.; software, M.W. and M.G.; validation, M.W. and M.G.; formal analysis, M.W. and M.G.; investigation, M.W. and M.G.; resources, M.G.; data curation, M.W.; writing—original draft preparation, M.W. and M.G.; writingreview and editing, M.W. and M.G.; visualization, M.W.; supervision, M.G.; project administration, M.W. All authors have read and agreed to the published version of the manuscript.

Funding: This research received no external funding.

Acknowledgments: The authors would like to thank Daniel Bekus for the measurement with a laser profilograph on the tested road section and the possibility of making the measurement data available in this study.

Conflicts of Interest: The authors declare no conflict of interest.

\section{References}

1. European Commission. Communication from the Commission on a European Programme for Critical Infrastructure Protection, 2006th ed.; European Commission: Brussels, Belgium, 2006.

2. Hedel, R.; Boustras, G.; Gkotsis, I.; Vasiliadou, I.; Rathke, P. Assessment of the European Programme for Critical Infrastructure Protection in the surface transport sector. Int. J. Crit. Infrastruct. 2018, 14, 311. [CrossRef]

3. Kowalski, A. Deformacje Powierzchni na Terenach Górniczych Kopaln Węla Kamiennego; Wydawnictwo Głównego Instytutu: Górnictwa, Poland; Katowice, Poland, 2020. (In Polish)

4. Kwiatek, J. Ochrona Obiektów Budowlanych na Terenach Górniczych; Wydawnictwo Głównego Instytutu: Górnictwa, Poland; Katowice, Poland, 1997. (In Polish)

5. Gromysz, J.; Gromysz, K. Zachowanie Się Wiaduktu Kolejowego w Trakcie Prowadzenia Pod Nim Eksploatacji Górniczej Jako Przykład Reakcji Konstrukcji Budowlanej na Odkształcenia Terenu Górniczego; Główny Instytut Górnictwa: Katowice, Poland, 2011 ; pp. 135-149. (In Polish) 
6. Reddish, D.J.; Whittaker, B.N. Subsidence: Occurrence, Prediction and Control; Elsevier Science: Amsterdam, The Netherlands, 2012; ISBN 9780444598349.

7. Kratzsch, H. Mining Subsidence Engineering; Springer: Berlin/Heidelberg, Germany; New York, NY, USA, 1983; ISBN 978-3-642-81925-4.

8. Strzałkowiski, P.; Szafulera, K. Occurrence of linear discontinuous deformations in Upper Silesia (Poland) in conditions of intensive mining extraction-case study. Energies 2020, 13, 1897. [CrossRef]

9. Strzałkowski, P.; Piwowarczyk, J.; Łapajski, K. Występowanie deformacji nieciąłych liniowych w świetle analiz warunków geologiczno-górniczych. Przegląd Górniczy (Pol. Min. Rev.) 2006, 62, 1-5. (In Polish)

10. Ścigała, R.; Szafulera, K. Linear discontinuous deformations created on the surface as an effect of underground mining and local geological conditions-Case study. Bull. Eng. Geol. Environ. 2019, 79, 2059-2068. [CrossRef]

11. Orwat, J. Causes analysis of occurrence of the terrain surface discontinuous deformations of a linear type. J. Phys. 2020, 1426, 012016. [CrossRef]

12. Kowalski, A.; Kotyrba, A. Linear discontinuous deformation of A4 highway within mining area Halemba. Miner. Resour. Manag. 2009, 25, 303-317.

13. Grygierek, M.; Sternik, K. Identification of Pavement Model Parameters in the Area of Discontinuous Surface Deformation Based on FWD Tests. Int. J. Civ. Eng. 2021, 19, 265-282. [CrossRef]

14. Dabrowski, P.; Ejsmont, S.; Foryś, G.; Franciszkiewicz, J.; Gromada, W.; Łuczak, R. Diagnostyka Stanu Nawierzchni i jej Elementów. Wytyczne Stosowania [Assessing Condition of Pavement and Its Elements. Guidelines]. Warszawa: Generalna Dyrekcja Dróg Krajowych i Autostrad. Available online: https://www.gddkia.gov.pl/userfiles/articles/z/zarzadzenia-generalnego-dyrektor_ 17474/zarzadzenie34zalacznikwytycznestosowania.pdf (accessed on 21 November 2017). (In Polish)

15. Wróblewska, M. Measurement methods of building structures deflections. E3S Web Conf. 2018, 36, 02010. [CrossRef]

16. Szade, A. Monitoring Obiektów Budowlanych Na Terenach Górniczych Laserowymi Czujnikami Drgań, Wychyleń i Deformacji; Główny Instytut Górnictwa: Katowice, Poland, 2010; pp. 338-347. (In Polish)

17. Casadei, P.; McCombie, P.; Nanni, A.; Galati, N. NDT Monitoring of Bridges using Innovative High Precision Surveying System IABSE Symp. Rep. 2006, 92, 50-57. [CrossRef]

18. Vrublová, D.; Kapica, R.; Gibesová, B.; Mudruňka, J.; Struś, A. Application of GNSS technology in surface mining. Geod. Cartogr. 2016, 42, 122-128. [CrossRef]

19. Bahuguna, P.P.; Kumar, D.; Kumar, S. Modern Survey Instruments and their use in Mine Surveying. In Proceedings of the Indian Conference on Mine Surveying (ICMS-2006), Indian School of Mines Dhanbad, Jharkhand, India, 8-9 September 2006.

20. Ren, H.; Zhao, Y.; Xiao, W. A review of UAV monitoring in mining areas: Current status and future perspectives. Int. J. Coal Sci. Technol. 2019, 6, 320-333. [CrossRef]

21. Lay, U.S.; Pradhan, B.; Yusoff, Z.B.M.; Abdallah, A.F.B.; Aryal, J.; Park, H.-J. Data Mining and Statistical Approaches in Debris-Flow Susceptibility Modelling Using Airborne LiDAR Data. Sensors 2019, 19, 3451. [CrossRef] [PubMed]

22. Bui, X.N.; Anh, V.; Bui, L.; Long, N.; Le Thi Thu, H.; Goyal, R. Mining-Induced Land Subsidence Detection by Persistent Scatterer InSAR and Sentinel-1: Application to Phugiao Quarries, Vietnam. In Proceedings of the International Conference on Innovations for Sustainable and Responsible Mining, Hanoi, Vietnam, 15-17 October 2020; Springer: Berlin/Heidelberg, Germany, 2020; pp. 18-38. [CrossRef]

23. Lian, X.; Liu, X.; Ge, L.; Hu, H.; Du, Z.; Wu, Y. Time-series unmanned aerial vehicle photogrammetry monitoring method without ground control points to measure mining subsidence. J. Appl. Remote Sens. 2021, 15, 024505. [CrossRef]

24. Sayers, M.W.; Gillespie, T.D.; Queiroz, Q. The International Road Roughness Experiment: Establishing Correlation and a Calibration Standard for Measurements; World Bank Technical Paper No. 45; The World Bank: Washington, DC, USA, 1986.

25. ARA. Guide for mechanistic-empirical design of new and rehabiltated pavement structures. In National Cooperative Highway Research Program; ARA, Inc.: Champaign, IL, USA, 2004.

26. Chen, S.-L.; Lin, C.-H.; Tang, C.-W.; Chu, L.-P.; Cheng, C.-K. Research on the International Roughness Index Threshold of Road Rehabilitation in Metropolitan Areas: A Case Study in Taipei City. Sustainability 2020, 12, 10536. [CrossRef]

27. Pérez-Acebo, H.; Bejan, S.; Gonzalo-Orden, H. Transition Probability Matrices for Flexible Pavement Deterioration Models with Half-Year Cycle Time. Int. J. Civ. Eng. 2018, 16, 1045-1056. [CrossRef]

28. Gkyrtis, K.; Loizos, A.; Plati, C. Integrating Pavement Sensing Data for Pavement Condition Evaluation. Sensors 2021, $21,3104$. [CrossRef]

29. Gong, H.; Sun, Y.; Shu, X.; Huang, B. Use of random forests regression for predicting IRI of asphalt pavements. Constr. Build. Mater. 2018, 189, 890-897. [CrossRef]

30. Mubaraki, M. Highway subsurface assessment using pavement surface distress and roughness data. Int. J. Pavement Res. Technol. 2016, 9, 393-402. [CrossRef]

31. ASTM E1926-08; Standard Practice for Computing International Roughness Index of Roads from Longitudinal Profile Measurements. ASTM International: West Conshohocken, PE, USA, 2021.

32. AASHTO R 43M/R 43-07; Standard Specifications for Transportation Materials and Methods of Sampling and Testing. American Association of State Highway and Transportation Officials: Washington DC, USA, 2008.

33. Sayers, M.W.; Karamihas, S.M. The Little Book of Profiling: Basic Information about Measuring and Interpreting Road Profiles; University of Michigan Transportation Research Institute: Ann Arbor, MI, USA, 1998. 
34. Bridgelall, R.; Huang, Y.; Zhang, Z.; Deng, F. Precision enhancement of pavement roughness localization with connected vehicles. Meas. Sci. Technol. 2016, 27, 025012. [CrossRef]

35. Piryonesi, S.M.; El-Diraby, T.E. Examining the relationship between two road performance indicators: Pavement condition index and international roughness index. Transp. Geotech. 2020, 26, 100441. [CrossRef]

36. Radović, N.; Jokanović, I.; Matić, B.; Šešlija, M. A measurement of roughness as indicator of road network condition-case study serbia. Teh. Vjesn. 2016, 23, 881-884. [CrossRef]

37. Judycki, J.; Jaskuła, P.; Pszczoła, M.; Ryś, D.; Jaczewski, M.; Alenowicz, J.; Dołzycki, B.; Stienss, M. New polish catalogue of typical flexible and semi-rigid pavements. MATEC Web Conf. 2017, 122, 04002. [CrossRef]

38. Celko, J.; Decky, M.; Kovac, M. An Analysis of Vehicle-Road Surface Interaction for Classification of IRI in the Frame of Slovak PMS. Maint. Reliab. 2009, 41, 15-21.

39. General Directorate for National Roads and Motorways (GDDKiA). Asphalt Pavements on National Roads, Technical Requirements WT-2, Asphalt Pavements; GDDKiA: Warsaw, Poland, 2012. 